\title{
REFLEXÕES SOBRE A ARTE "PRIMIIIVA": O CASO DO MUSÉE BRANLY
}

\author{
Ilana Goldstein* \\ Universidade Estadual de Campinas - Brasil
}

Resumo: Na época das descobertas ultramarinas, os europeus acumulavam fragmentos das novas realidades que encontravam em suas viagens, nos chamados gabinetes de curiosidades. Os colecionadores se especializaram e, a partir do século $X V I I I$, surgiram os primeiros museus científicos. No final do século XIX, as exposições universais expunham a "barbárie" dos povos colonizados. Já as vanguardas do século XX redescobriram a arte "primitiva" enquanto fonte de renovação. Este artigo recupera tais formas de apreensão da cultura material de sociedades tradicionais ao longo do tempo, para chegar à inauguração do Musée Branly, em 2006. A partir desse museu, podem-se repensar algumas questões fundamentais acerca da arte "primitiva", como a dicotomia entre tratar os artefatos como testemunhos etnográficos ou como criações estéticas; as relações de poder envolvidas na aquisição dos objetos; o problema da autenticidade, numa era em que se multiplicam os souvenirs étnicos "neotradicionais".

Palavras-chave: antropologia da arte, arte "primitiva”, Musée Branly, museologia.

Abstract: In the epoch of overseas discoveries, Europeans accumulated fragments of the realities they found in cabinets of curiosities. The private collectors specialized in different branches of "natural history" and this led to the emergence of scientific museums in the 18th century. At the end of the 19th century, universal exhibitions displayed "primitive" artifacts side by side with Western technologies, suggesting the "barbarism" of colonized peoples. But, at the beginning of the 20th century, the avant-gardes rediscovered the art nègre, using it as a source of artistic renovation. This article begins by describing these various forms of dealing with the cultural

* Doutoranda em Antropologia Social.

Horizontes Antropológicos, Porto Alegre, ano 14, n. 29, p. 279-314, jan./jun. 2008 
expressions of others, in order to understand the meaning of the recently opened Musée Branly. The French museum, devoted to non-occidental societies, provides an opportunity to reconsider some fundamental issues. Should we exhibit these artifacts as ethnographic testimonies or works of art? Can we expect traditional "authenticity" in a global era? What are the ethical issues involved in the acquisition of these objects? In the last part of the article, the notion of "primitive" art itself is put into question.

Keywords: anthropology of art, Musée Branly, museology, "primitive” art.

\section{Arte e antropologia: aproximações}

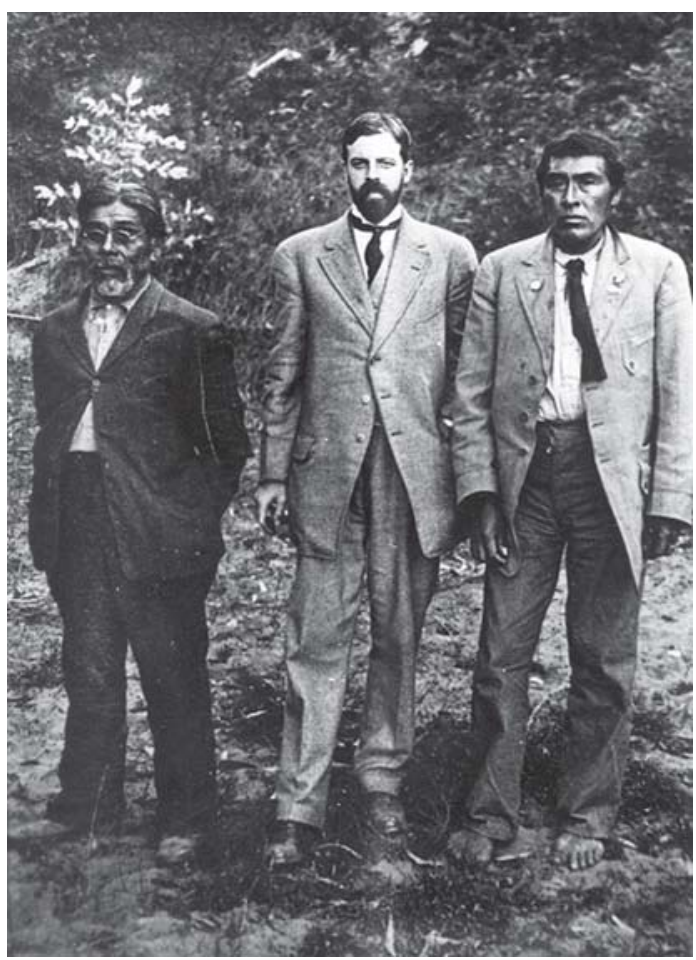

Figura 1. Da esquerda para a direita: Sam Batwi (yana), A.L. Kroeber (Universidade da Califórnia) e Ishi (yahi), em 1911. Acervo do Phoebe Hearst Museum of Anthropology.
Ishi era ainda criança quando o povo yahi foi massacrado por colonizadores brancos, no Norte da Califórnia. Após 35 anos se escondendo, em agosto de 1911, foi encontrado, faminto e com os cabelos queimados, nos arredores de Oroville. Rapidamente, "o selvagem de Oroville" tornou-se uma sensação na imprensa. Waterman, da Universidade da Califórnia, fez contato com Ishi, que foi levado para o Museu de Antropologia de São Francisco, onde viveu sob os cuidados de Alfred Kroeber e sua equipe, antes de morrer de tuberculose, em 1916. Essa história foi popularizada pelo livro da viúva de Kroeber (Kroeber, 1961) que, com base nas notas do marido, reconstituiu o drama do último representante do povo yahi. 
Em 1990, a artista plástica Claire Pentecost realizou uma instalação inspirada em Ishi. Sua matéria-prima foram as respostas aos questionários que havia enviado a nativos norte-americanos, pedindo que relatassem o que sabiam e o que pensavam sobre o caso Ishi. A proposta de Claire era revelar a contradição presente nas sociedades com passado colonial que, ao mesmo tempo em que idealizam os indígenas, destroem comunidades inteiras e tomam suas terras (Schneider, 2006, p. 50).

Obras que discutem a história das relações entre civilizações ocidentais e não-ocidentais também se fizeram presentes na exposição Retracing Territories, que ficou em cartaz no Centro de Arte Contemporânea de Friburgo (Fri-Art), em 2007. ${ }^{1} \mathrm{O}$ artista Hinrich Sachs explorou a construção dos chamados museus de civilizações, problematizando particularmente as intenções de Jacques Chirac, ao inaugurar, em junho de 2006, o Musée du Quai Branly. O trabalho de Hinrich Sachs organizava-se em torno do discurso do então presidente francês, ${ }^{2}$ indagando qual o seu verdadeiro programa político e sugerindo que o divertimento e o turismo norteariam aquele "museu-espetáculo".

Na mesma exposição suíça, Uriel Orlov mostrou um vídeo sobre seu encontro com Oba Erediauwa, rei do Benin. ${ }^{3}$ No filme, um narrador local acompanha o artista ao palácio de Oba e relata a conversação entre o visitante europeu e o anfitrião real, acompanhado da corte e de alguns chefes. Um dos temas da conversa é o caso dos bronzes do Benin, pilhados pelos britânicos em 1897 e hoje distribuídos em cerca de 500 museus e coleções em todo o mundo. Coincidentemente, uma das mostras mais recentes do Musée du Quai Branly, chamada Bénin: Cinq Siècles d'Art Royal, reuniu, entre outubro de 2007 e janeiro de 2008, peças de bronze e mármore do Reino do Benin, provenientes de coleções inglesas a austríacas.

Portanto, as relações entre arte e antropologia parecem estar em pauta, não apenas nas ciências sociais, mas também nos meios artísticos. Se exami-

\footnotetext{
${ }^{1}$ Para mais informações sobre a Kunsthalle Fribourg, acessar o site: http://www.fri-art.ch/data/ flash.html.

${ }^{2}$ Em seu discurso inaugural, o então presidente Jacques Chirac admitiu que muitos dos objetos presentes naquele edifício tinham sido adquiridos, ao curso de uma história colonial, em condições bem distantes de uma verdadeira troca entre iguais (Latour, 2007, p. 97).

${ }^{3}$ Uriel Orlov realizou vários outros trabalhos dentro de seu Benin Project. Ver: http:// www.urielorlow.net.
} 
narmos as primeiras décadas do século $\mathrm{XX}$, perceberemos que o interesse dos artistas por outras culturas já se faz presente, embora desprovido do questionamento político e moral inerente aos trabalhos contemporâneos mencionados acima.

É impressionante - embora já tenha sido bastante discutida - a semelhança entre os rostos angulosos, geométricos e coloridos das Demoiselles d'Avignon (1907) de Picasso e certas máscaras africanas. No caso de Paul Gauguin, o "primitivismo" se traduziu em distanciamento geográfico. O desejo de partir acometeu vários artistas da virada do século XIX para o XX, ansiosos por encontrar contextos mais adequados para uma criação artística "pura" do que os centros urbanos “civilizados” (Perry, 1998). O afastamento de Gauguin começou pela Bretanha, região agrícola e tradicional da França, e culminou com sua mudança para o Taiti - provavelmente influenciada pela representação literária paradisíaca daquela colônia francesa. Como explica Perry (1998, p. 8):

O “ir embora” para províncias rurais distantes - ou para as supostas margens da civilização - passou a ser visto como um aspecto crucial. [...] Costumava ser combinado com a produção de uma obra num estilo "primitivo". [...] O culto do "ir embora" não era de forma alguma exclusivo do vanguardismo francês e do círculo em torno de Gauguin. Em toda a Europa, inclusive a Rússia, a Escandinávia e a Inglaterra, e na Alemanha em particular, a voga de formar comunidades e colônias de artistas longe dos centros urbanos havia sido estabelecida em meados do século XIX.

Entre os pintores fauvistas, havia vários colecionadores de arte não-ocidental. Matisse, Vlaminck e Derrain adquiriram, na mesma época que Picasso, peças da África e da Oceania. Na pintura dos três, a influência das máscaras rituais se reflete, por exemplo, na escolha de olhos em formato de losango e rostos estilizados. Também no grupo dos surrealistas, alguns anos depois, emergiria um forte interesse pelos “primitivos”.

James Clifford (1996) mostra o quanto o surgimento do Institut d'Ethnologie, por iniciativa de Marcel Mauss, Lévy-Bruhl e Paul Rivet, esteve entrelaçado com a emergência do movimento surrealista, encabeçado por André Breton, Michel Leris e Raymond Queneau. O ano de fundação do instituto de etnologia parisiense foi o mesmo da publicação do Manifesto Surrealista: 1925. A revista Documents, editada por Georges Bataille, publicava lado a lado textos de artistas e de etnólogos. Alguns surrealistas iriam mesmo partir à África, com a 


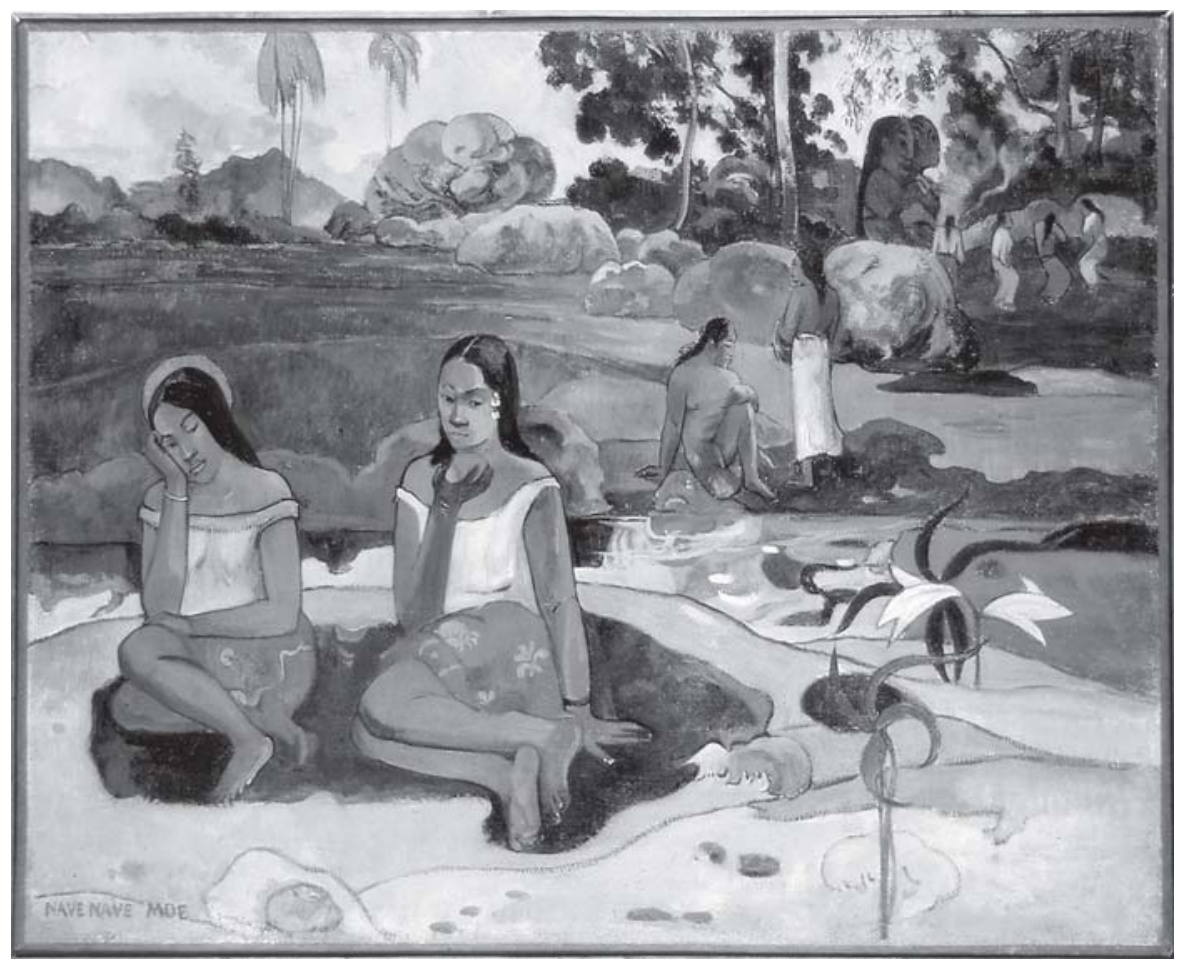

Figura 2. Paul Gauguin, Nave Nave Moe, 1894. Óleo sobre tela, Museu Hermitage, São Petesburgo.

missão Dakar-Djibouti ${ }^{4}$ (1931-1933). Encabeçada por Marcel Griaule, a expedição tinha como objetivos a pesquisa de campo e a ampliação das coleções francesas, e seus fundos vieram, em grande parte, da doação de mecenas. Naquele momento, o interesse pelo Outro unia artistas, amantes das artes e etnólogos.

4 A Dakar-Djibouti foi organizada pela Universidade de Paris e pelo Muséum National d’Histoire Naturelle. Partiu de Dakar, atravessando o Senegal, o Sudão (atual Mali), Benin, Nigéria, Camarão, Congo e Etiópia, até chegar em Djibouti. A quantidade de material coletado é impressionante: 3,6 mil objetos, 3 mil fotografias, 200 registros sonoros e 300 manuscritos, todos destinados ao Musée Trocadéro. Entre os participantes da missão, estavam Michel Leris, André Schaeffner, Deborah Lifchitz e Marcel Griaule (Degli; Mauzé, 2006, p. 91).

Horizontes Antropológicos, Porto Alegre, ano 14, n. 29, p. 279-314, jan./jun. 2008 
Segundo Clifford, no início do século XX, a África, a Oceania e a América eram vistas como um reservatório de novas formas e valores. Nas décadas de 1920 e 1930, a atitude etnográfica representava a possibilidade de uma crítica cultural subversiva e da relativização da sociedade moderna ocidental.

Below (psychologically) and beyond (geographically) ordinary reality, there existed another reality. Surrealism shared this ironic situation with relativist ethnography. [...] The surrealists were intensely interested in exotic worlds [...]. The fieldworker who strives to render the unfamiliar comprehensible tended to work in the reverse sense, making the familiar strange. (Clifford, 1996, p. 120-127).

Há dois pontos em comum entre todos esses artistas modernos. Em primeiro lugar, o elemento "primitivo" lhes serviu como um signo de modernidade, como um emblema da filiação a formas expressivas mais "autênticas" e radicais. Em segundo lugar, o exótico foi recriado por eles de acordo com os pressupostos e práticas ocidentais da época - e, portanto, sob a égide da política colonial européia. Gill Perry (1998, p. 56) ressalta, a esse respeito:

A ausência de uma iconografia ou uma história acessíveis desses objetos permitia que eles fossem facilmente absorvidos numa cultura artística moderna. Essa descontextualização é uma das várias razões pelas quais os artistas modernos foram acusados de responder de modo etnocentrista à arte africana e da Oceania, atribuindo a suas aparências (significantes) sentidos ocidentais do século XX (significados).

Passadas várias décadas, a complexidade e a riqueza dos diálogos entre o campo artístico e a antropologia permanecem, como atestam os trabalhos contemporâneos de Claire Pentecost, Hinrich Sachs, Uriel Orlov e de muitos outros artistas que não seria possível citar aqui. A recente inauguração do Musée Branly, às margens do rio Sena, trouxe à tona algumas questões relativas a esse diálogo. Por que a chamada arte "primitiva” tanto fascina os ocidentais? De que modo ela deve ser compreendida e exibida por nós? Quais as relações de poder implicadas na aquisição e na exposição de objetos de outras sociedades?

O presente artigo consiste em um primeiro esforço de reflexão sobre o significado do Musée Branly. Começa com um breve histórico, procurando situar o novo museu parisiense, dedicado às "artes primeiras”, dentro de uma determinada tradição de coleções e exposições. Em seguida, parte do caso do 
Musée Branly para levantar questões gerais sobre o estudo e a exposição da arte "primitiva”. Sem a pretensão de esgotar tema tão vasto e espinhoso, o objetivo é traçar um panorama geral e introdutório, sugerindo de que maneira a história da arte, a museologia e a antropologia permitem interfaces interessantes e analiticamente férteis.

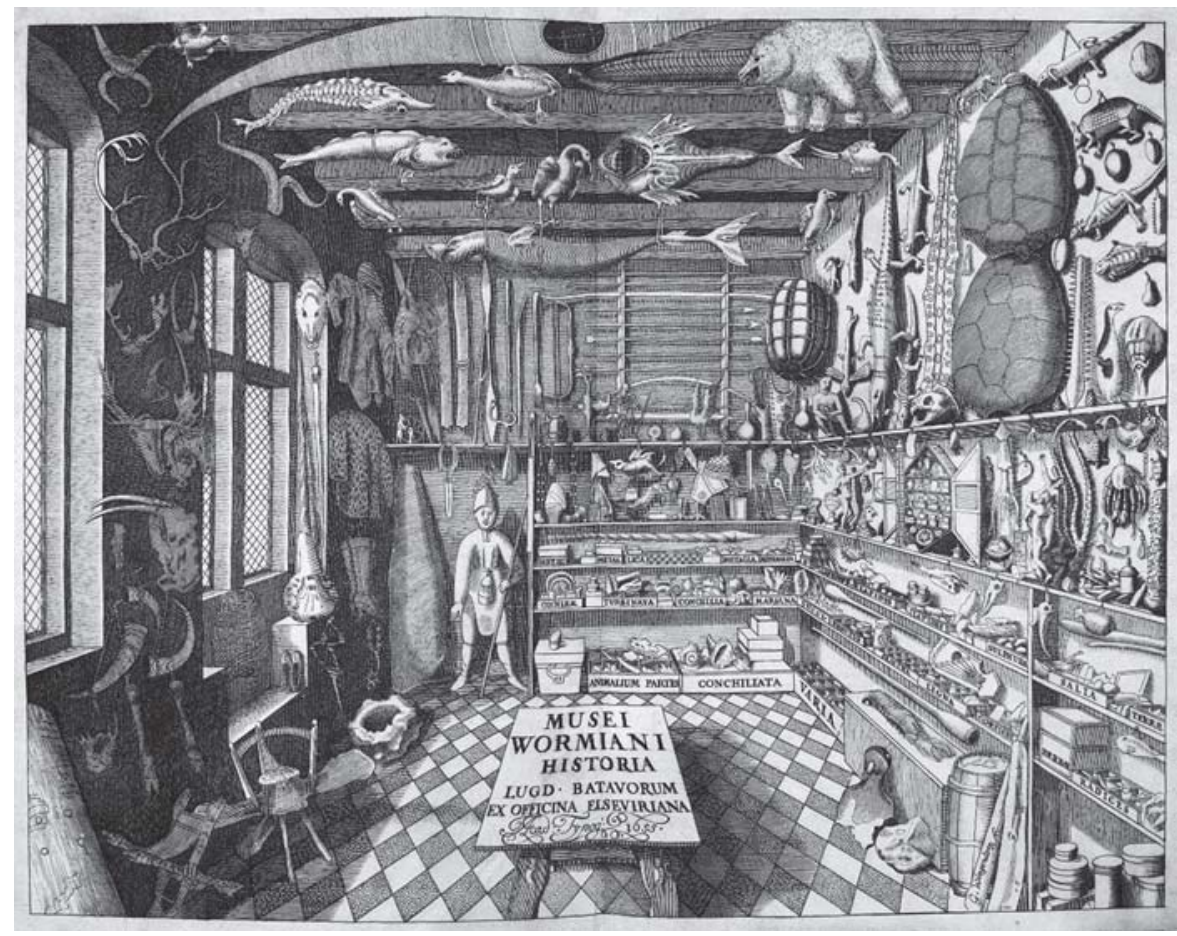

Figura 3. Folha de rosto do livro Museum Wormianum, catálogo do gabinete de curiosidades do médico e colecionador dinamarquês Olw Worm (1588-1655).

\section{Dos gabinetes de curiosidades aos museus}

Durante os séculos das descobertas ultramarinas, os europeus acumularam os fragmentos das realidades estranhas encontradas em suas viagens, nos chamados gabinetes de curiosidades, que se multiplicaram do século XVI ao 
XVIII (Aguilar, 2000). Os gabinetes de curiosidades tinham um caráter de coleção enciclopédica, acumulando tudo o que chegava de lugares distantes e desconhecidos. Não havia preocupação em nomear ou classificar, mas apenas em evidenciar, pelas amostras, a existência de outras civilizações. As coleções dos gabinetes eram organizadas em dois grandes eixos: Naturalia e Mirabilia.

Do primeiro, fazem parte exemplares dos reinos animal, vegetal e mineral. Já o segundo divide-se, por sua vez, em duas seções: os objetos produtos da ação humana (Artificialia) e as antigüidades e objetos exóticos que remetem a povos desconhecidos, normalmente vendidos aos colecionadores ou presenteados por viajantes e marinheiros. (Possas, 2005, p. 153).

De acordo com Helga Possas (2005), a motivação inicial dos donos de gabinetes de curiosidades era tentar possuir o inatingível, para desvendar o mistério da criação. Por um lado, essas coleções particulares funcionavam como emblema de poder e prestígio social. Por outro, foram elas que suscitaram uma organização cada vez mais científica. À medida que foram crescendo, ficou patente a necessidade de locais apropriados para guardar os novos objetos de conhecimento. Alguns colecionadores foram se especializando e assim surgiram estudiosos de zoologia, botânica e outros ramos da "história natural".

Paulatinamente, os museus se tornaram instituições de pesquisa que atuavam ora isoladamente, ora vinculados a universidades, até que as coleções assumiram definitivamente o caráter científico. Passaram a servir à elaboração do conhecimento, apoiado em observações, pesquisas e construções teóricas. O desenvolvimento da ciência nos séculos XVIII e XIX esteve fortemente associado ao surgimento e consolidação de museus (Possas, 2005, p. 159).

Lilia Schwarcz (2005, p. 125) assim se refere à "era dos museus”, no século XIX:

O final do século XIX viu florescer uma série de museus etnográficos, profundamente vinculados aos parâmetros biológicos de investigação e os modelos evolucionistas de análise. [...] O primeiro centro desse gênero, de caráter ainda não estritamente antropológico, foi o British Museum, fundado em 1753, contando com um acervo ampliado das explorações do Capitão Cook. No entanto, é no XIX que o movimento se amplia com a criação de instituições como o Museu Etnográfico de São Petersburgo (1866), o National Museum de Leiden (1837) e o Peabody Museum (1866). 
Nas últimas décadas do século XIX, foram organizadas as Exposições Universais, verdadeiras justificativas encenadas do empreendimento colonizador. Ao lado das conquistas coloniais - agrícolas, florestais, minerais -, havia espaço para mostrar tradições locais das colônias. A principal finalidade era enfatizar a "barbárie" dos povos exóticos, justificando a intervenção européia (Degli; Mauzé, 2006, p. 62). Uma das conseqüências da organização dessas exposições foi o incremento das coleções museográficas.

\section{Antecedentes do Quai Branly: Irocadéro e Musée de l'Homme}

A primeira exposição de arte pré-colombiana na França foi organizada por Georges-Henri Rivière, na década de 1920. O sucesso da mostra foi tamanho, que Paul Rivet o convidou para reorganizar as coleções do Musée Trocadéro, no início da década de 1930. O acervo do Trocadéro carecia de classificação e contextualização. Reunia peças exóticas em abundância, dispostas sem quaisquer preocupações pedagógicas ou científicas. Foi no Trocadéro que Picasso iniciou seus estudos de art nègre, em 1908. (Clifford, 1996, p. 137).

Em 1935, mal haviam terminado as reformas no Trocadéro e Paul Rivet anunciou um novo projeto, ao mesmo tempo científico e político: construir um grande e moderno museu dedicado a celebrar a humanidade. O Musée de l'Homme, instalado no Palais de Chaillot e inaugurado em junho de 1938, iria abrigar sob seu teto os técnicos dos laboratórios do antigo Museu de História Natural e os pesquisadores do Instituto de Etnologia, ambos sediados na Sorbonne, até então. Clifford escreve sobre esse momento:

Rivet had gathered together a talented group of ethnologists including Métraux, Leroi-Gourhan, Leenhardt, Griaule, Leris, Schaefnner, Dieterlen, Paulme, Louis Dumont $[\ldots]$. For most of these scholars, the connection between art and ethnography was crucial. [...] The Musée de l'Homme provided a liberal, productive environment for the growth of French ethnographic science. Its guiding values were cosmopolitan, progressive and democratic; one of the first cells of the Resistance formed within its walls in 1940. (Clifford, 1996, p. 138-139).

Muitas gerações de pesquisadores se sucederam, várias exposições foram organizadas e o Musée de l'Homme se tornou uma referência internacional. Contudo, nas duas últimas décadas, talvez em virtude da escassez de verbas, os recursos expositivos do Musée de l'Homme eram antiquados e sua taxa 
de visitação, baixa. Jacques Kerchache, colecionador de arte africana e amigo de Jacques Chirac, estimulou o presidente francês a transferir os acervos do Musée de L'Homme e também do Musée National des Arts d'Afrique et d'Océanie ${ }^{5}$ para um edifício mais moderno e atraente. A decisão gerou reações por parte de alguns antropólogos, pelo fato de que o Musée de l'Homme era um importante e tradicional centro de pesquisas e em virtude do eixo curatorial do novo museu privilegiar o aspecto plástico.

Hoje, o acervo do Musée du Quai Branly conta com mais de 300 mil objetos e seu edifício é assinado pelo festejado arquiteto Jean Nouvel. A exposição permanente está dividida em três unidades: América, Ásia, África \& Oceania. Assim se autodefine a instituição:

Musée des arts et des civilisations d'Afrique, d'Asie, d'Océanie et des Amériques, le musée affirme ao coeur de Paris la reconnaissance et la promotion du patrimoine culturel non occidental. Il présente um regard neuf sur ces cultures à travers une programmation diversifiée d'expositions permanentes et temporaires, de spectacles, de conférences-débats, de visites contées et d'ateliers. [...] Ces collections sont emblématiques d'une histoire des relations internationals de la France avec le monde extra-européen au cours des siècles passés, et d'une histoire des sciences humaines en Europe. ${ }^{6}$

Percebe-se, no discurso institucional, uma certa preocupação de dar espaço ao Outro e de contextualizar os contatos interculturais entre europeus e não-ocidentais. Contudo, predomina a intenção de transformar a nova instituição em um ponto turístico nacional e internacional, voltado ao lazer e à diversão acessíveis ao grande público. Talvez seja em virtude dessa contradição aparen-

\footnotetext{
5 Por ocasião da Exposition Coloniale de la Porte Dorée, em 1931, decidiu-se construir um museu dedicado às colônias, cuja tônica era enaltecer o "bom selvagem", vivendo de modo simples e harmonioso, e disposto a aceitar os colonizadores. O tom de apologia ao colonialismo daquele novo Musée de la France d'Outre-Mer fez com que os surrealistas escrevessem um manifesto conclamando: “Não visitem a exposição colonial!” (Degli; Mauzé, 2006, p. 94). Em 1962, o ministro da cultura André Malraux decidiu reformar e rebatizar o museu com o nome de Musée des Arts Africans et Océanians. O fato de ficar situado perto do bosque de Vincennes e de possuir um aquário com peixes ornamentais em seu subsolo fazia com que aquele fosse um museu bastante visitado por famílias, nos finais de semana.

${ }^{6}$ O trecho foi retirado do folder de divulgação La Visite des Seniors 2006-2007, de distribuição gratuita, no próprio museu, desde junho de 2006.
}

Horizontes Antropológicos, Porto Alegre, ano 14, n. 29, p. 279-314, jan./jun. 2008 
te que, na primeira publicação disponível no Branly, um catálogo com 80 obras selecionadas do acervo, o diretor Stéphane Martin afirme, sem qualquer ressalva, que é possível se falar em "obras-primas” africanas, asiáticas ou australianas, da mesma maneira que se fala em "obras-primas" no Ocidente; que seu foco é mostrar o "gênio inventivo" dos autores das peças e que "a escolha é incontestável em termos artísticos” (Musée du Quai Branly, 2006, p. 5, tradução minha).

Vale mencionar que o logotipo do Musée Branly é uma estatueta chamada Chupicuaro, originária das montanhas do México Central. Seu nome vem do sítio arqueológico no qual foi encontrada e, na verdade, a Chupicuaro não fica no Quai Branly, mas no Pavillon des Sessions, dentro do Louvre. ${ }^{7}$ De acordo com as informações do museu, a peça teria servido a um rito funerário, ligado à fertilidade da terra e ao ciclo do renascimento. Caracterizada por formas arredondadas e volumosas e pelo colorido vermelho, preto e branco, que não perdeu o brilho apesar de seus 25 séculos de idade, o curioso é que a estatueta se autoapresenta, em primeira pessoa, no site da instituição. Descreve a si mesma como uma "obra de arte", que seduz pela "modernidade" de seus grafismos: "Mon statut de chef-d'œuvre m'a valu cette place dans le temple de l'Art. En effet, je [...] charme les yeux par la modernité de mon graphisme et par l'éclat de mes coloris". ${ }^{8}$

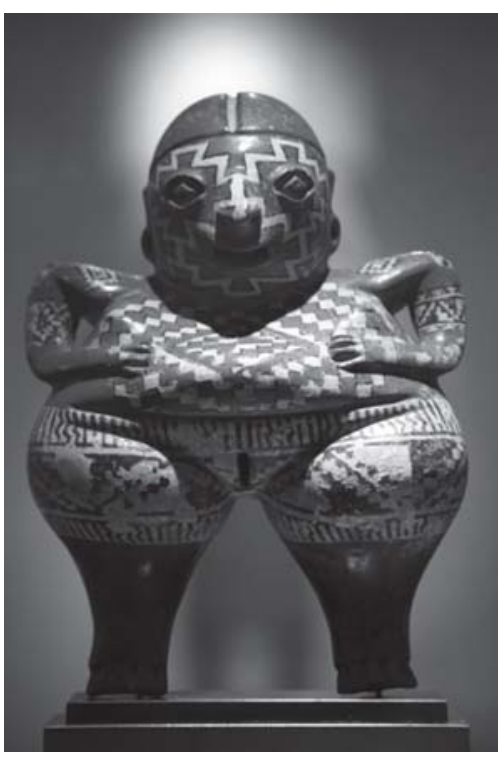

Figura 4. La Chupicuaro (México, cerca de 400 a.C.), logotipo do Musée Branly. Divulgacão.

7 O Pavillon des Sessions é o conjunto de salas das “artes primeiras” no Louvre, que foi uma espécie de “projeto-piloto” do Musée Branly. Ele existe desde 2000 e representou um grande marco. Embora sejam oferecidas informações em telas interativas, que permitem ao visitante buscar informações sobre o contexto de origem das obras, o que mais impressiona nessa nova seção do Louvre é a cenografia teatral, que põe em destaque as cores e formas de cada peça.

8 Trecho retirado do site do Musée Branly, seção “La Chupicuaro” (http://www.quaibranly.fr/fr/ collections/la-chupicuaro/index.html). 


\section{Duas exposições pioneiras}

A concepção do Musée Branly foi possível, em grande parte, devido ao caminho que fora aberto por outras mostras que classificavam na categoria de arte objetos coletados em sociedades não-ocidentais. A mostra Primitivism in 20th Century Art: Affinity of the Tribal and the Modern, realizada no MoMA, em Nova Iorque, no inverno de 1984/1985, tematizou a redescoberta da art nègre pelas vanguardas modernas e foi a primeira grande aparição de artefatos de sociedades não-ocidentais em um museu de belas-artes. O curador William Rubin reuniu peças de museus etnográficos europeus, de galerias especializadas e de coleções particulares e as expôs lado a lado com obras de mestres ocidentais modernos, como Picasso, Giacometti e Brancusi. A idéia era mostrar aos visitantes o quão semelhantes eram suas formas (Rubin, 1984).

A crítica negativa que antropólogos fizeram ao evento referia-se à ênfase excessiva nas afinidades formais, que acabavam por encobrir desigualdades culturais e políticas (cf. Price, 2000, p. 11). Criava-se uma atmosfera de aparente comunhão, para revelar que os artistas ocidentais seriam geniais, por terem descoberto e recriado "primitivos" anônimos e atemporais. A percepção dos africanos, maori e kwakwiutl sobre a arte ocidental moderna em nenhum momento foi requisitada, tampouco artistas modernos dos países em desenvolvimento foram convidados a expor. Além disso, as diferenças entre o significado e o processo de fabricação da arte "primitiva" e da arte moderna ocidental foram apagadas, em nome da primazia da afinidade formal. Conforme James Clifford (1996), a mensagem da exposição se resumia à idéia de que, se as máscaras africanas pareciam tanto com Picasso, Brancusi e Paul Klee, elas deveriam ser valiosas esteticamente.

A grande novidade da mostra foi tomar o partido do impulso criador supostamente universal, como algo que une homens de diferentes épocas e culturas. Simultaneamente, abria-se mão de identificar e situar artistas e povos nãoocidentais. Nas palavras de Clifford:

At MoMA treating tribal objects as art means excluding the original cultural context. Consideration of context, we are firmly told at the exhibition's entrance, is the business of anthropologists. Cultural background is not essential to correct aesthetic appreciation and analysis: good art, the masterpiece, is universally recognizable. [...] Nothing on West Fifty-third suggests that good tribal art is beeing produced in the 1980s. The non-western artifacts on display are located

Horizontes Antropológicos, Porto Alegre, ano 14, n. 29, p. 279-314, jan./jun. 2008 
either in a vague past (reminiscent of the label 'nineteenth-twentieth century' that accompanies African and Oceanian pieces at the Metropolitan Museum’s Rockfeller Wing) or in a purely conceptual space defined by ‘primitive’ qualities: magic, ritualism, closeness to nature, mythic or cosmological aims. (Clifford, 1996, p. 202).

Poucos anos depois, Magiciens de la Terre, realizada no Centro Pompidou e na Grande Halle de La Villete, em Paris, de maio a agosto de 1989, veio se contrapor à mostra do MoMA. Conforme consta no catálogo, assinado pelo curador Jean-Hubert Martin, a mostra se pretendia “pós-moderna”, dando ao Outro voz, nome e rosto. Queria também tornar os termos internacional e contemporâneo "abrangentes" e "inclusivos" e criticava a concepção da exposição do MoMA, por excluir os "primitivos" da cena, como se fossem irracionais e dispensáveis.

O curador Jean-Hubert Martin visitou artistas não-ocidentais contemporâneos nos quatro cantos do globo, para romper, em primeira instância, com a idéia de que obras "primitivas" são arcaicas. Alguns artistas ocidentais também foram convidados por ele para a mostra do Pompidou, notadamente aqueles que estabeleciam relações com outras culturas, seja pela origem, seja pelo teor das obras. Os dois eixos curatoriais principais de Magiciens de la Terre foram a discussão da mudança de significado dos objetos na passagem de uma cultura a outra e a comprovação de que existe autoria artística "primitiva”. Um dos principais desdobramentos da exposição do Pompidou foi a ascensão de alguns artistas em seus países de origem, como é o caso de Bruly Bouabré e também Cyprien Tokoudagba, que esteve na penúltima Bienal de São Paulo. ${ }^{9}$

Por outro lado, a maior crítica que se fez à exposição francesa foi o fato de ela folclorizar e essencializar o não-ocidental, associando-o sempre ao arcaico, ao mágico, ao alternativo - o que deveria resultar bastante artificial, já

9 O curador Hubert-Martin também se notabilizou a partir de então e, até pouco tempo atrás, foi diretor do museu Kunst Palast, em Düsseldorf, no qual organizou a polêmica mostra Altares: Arte para se Ajoelhar, no inverno de 2001/2002. Sua idéia era aproximar as culturas por meio de objetos de devoção e explicitar o quanto a arte não-ocidental é indissociável da religiosidade. Alguns líderes religiosos acompanharam seus altares à exposição, para garantir que as obrigações e interdições fossem cumpridas, outros mandaram confeccionar réplicas para serem expostas no museu. Em meio aos altares mexicanos, africanos, coreanos, etc. havia também um pequeno altar católico e uma instalação voltada aos devotos de Elvis Presley. No entanto, em abril de 2006, Martin se demitiu do Kunst Palast alegando que a empresa de energia elétrica que patrocina o museu não concorda com o grande espaço que consagra à arte não-ocidental.

Horizontes Antropológicos, Porto Alegre, ano 14, n. 29, p. 279-314, jan./jun. 2008 
que foram convidados artistas como o brasileiro Cildo Meireles, completamente inserido no circuito internacional das artes. Vale destacar a ironia de Hermano Vianna (2004, p. 8-9) a respeito:

No dossiê que a revista Art Press publicou em maio de 1989 sobre essa exposição [...] havia uma entrevista com o curador Jean-Hubert Martin. Tive imensa dificuldade de acreditar no que estava lendo. [...] Logo a primeira resposta terminava assim (vale a pena citar todas as palavras): "não encontramos em todos os países onde fomos objetos que pudessem figurar na exposição. Na América do Sul, notadamente, fora o Brasil, tivemos decepções, pois encontramos artistas situados num sistema idêntico ao sistema da arte ocidental, com galerias, museus, etc. $E$ as produções desses artistas nos pareceram dependentes de nossos grandes centros, quando o que procurávamos era uma outra coisa - coisas que pudessem renovar o olhar, o interesse.” A entrevistadora lhe pede para explicar melhor o que procurava. A resposta, agora curta, é antológica: "Obras ancoradas em crenças e valores que não sejam aqueles de nossas redes artísticas. Não me interessava mostrar que os artistas da América Latina lêem a Artforum.

O aprendizado com essas duas grandes exposições pioneiras, somadas ao desejo de Jacques Chirac de deixar a marca de sua gestão no patrimônio cultural francês e ao provável interesse de Jacques Kerchache de valorizar o mercado de arte "primitiva" ajudam a compreender o contexto em que surgiu o Musée du Quai Branly. Voltemos a ele.

\section{0 cais das controvérsias}

Bernard Dupaigne foi diretor do Laboratório de Etnologia do Musée de l'Homme de 1991 a 1998. Transitou, assim, pelos bastidores do projeto de criação de um museu de artes "primeiras” em Paris, sobre o qual publicou um livro tão ressentido quanto repleto de informações de primeira mão sobre as nuanças e disputas que se escondem por trás do imponente Musée Branly.

De acordo com o relato de Bernard Dupaigne, a maioria dos pesquisadores do antigo Musée de l'Homme - que teve seu acervo transferido, exceto pelas peças consideradas européias, portanto não "primitivas” - acabou se aposentando precocemente ou pedindo transferência para outras instituições públicas, por não concordar com os métodos e as escolhas do diretor do Branly, Stephane Martin, que chegou a ser acusado de comprar peças nigerianas de origem ilegal. 


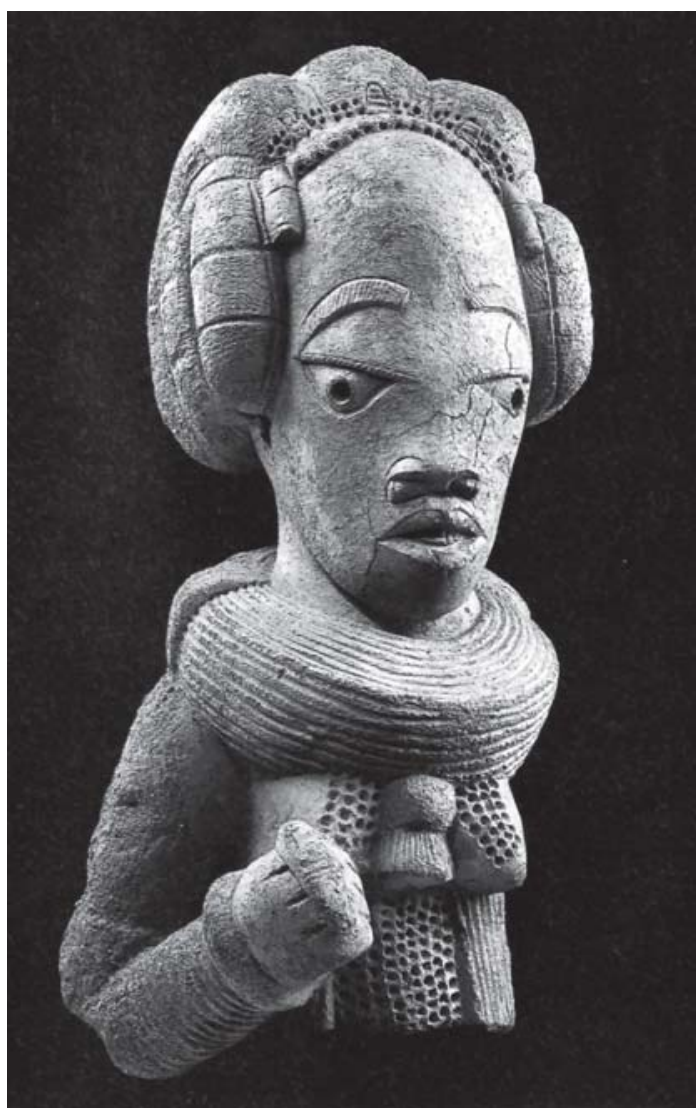

Figura 5. Estatueta nok (Nigéria, aprox. 250 a.C.) pertencente ao Musée Branly, semelhante à que está exposta dentro do Louvre, cuja legalidade da aquisição foi alvo de polêmicas, em 1999. Foto: Divulgação.
A acusação foi em 1999, quando o Musée Branly se encontrava em fase de construção. Três estátuas de terracota nok, da Nigéria, foram adquiridas a preços milionários para o acervo do museu, de forma ilegal, já que a Nigéria proíbe a saída dessas esculturas de seu território. ${ }^{10} \mathrm{O}$ mal-estar foi resolvido quando os ministros das culturas de ambos os países assinaram um documento, segundo o qual a propriedade jurídica da Nigéria sobre as peças fica assegurada, mas elas ficam sob guarda do Musée Branly por 25 anos - prazo renovável de comum acordo (Roux, 2000).

Sally Price (2007) conta que a idéia do Musée Branly surgiu casualmente, com o encontro entre Jacques Chirac e Jacques Kerchache em um hotel de luxo na Ilha Maurício, em 1992, quando os dois Jacques descobriram a paixão

${ }^{10}$ As esculturas nok são provenientes das regiões de Katsina e Sokoto, no Norte da Nigéria, onde estão os vestígios arqueológicos da civilização nok, que se desenvolveu de 900 a.C. ao ano 800 de nossa era. Pela lei nigeriana, todos os achados arqueológicos pertencem ao Estado. Na prática, de cerca de dez anos para cá, peças nok podem ser encontradas em leilões e exposições fora da Nigéria. O valor de cada terracota nok ultrapassa um milhão de euros (Roux, 2000).

Horizontes Antropológicos, Porto Alegre, ano 14, n. 29, p. 279-314, jan./jun. 2008 
comum pela arte africana. Chirac por hobby e Kerchache por profissão enriqueceu como marchand de arte primitiva e publicou uma antologia fotográfica sobre o tema. Chirac, prefeito de Paris desde 1989, elegeu-se presidente da França em maio de 1995. Kerchache lhe deu apoio durante a campanha. Poucos meses após a posse de Chirac, já estava nomeada uma comissão para estudar a possibilidade de expor peças de sociedades ágrafas da África, América e Oceania no Louvre, e para discutir uma reforma do Musée de l'Homme. A comissão de "artes primeiras” foi chefiada por um terceiro Jacques: Jacques Friedmann.

Alguns anos antes, Jacques Kerchache encabeçara um manifesto pela entrada das artes "primeiras” no Louvre. Naquele momento, não foram poucos os cientistas sociais a assinarem o documento. O manifesto, publicado no jornal Libération, no dia 15 de março de 1990, reclamava que o Louvre iria entrar no século XXI sem abrir espaço para objetos oriundos de culturas africanas, americanas, asiáticas, do Ártico e da Oceania, reproduzindo, portanto, a mentalidade colonial que fez com que "três quartos da humanidade" ficassem excluídos do principal museu francês. Pedia-se, então, a abertura de uma oitava seção no Grand Louvre, dedicada a esse tipo de produção. Assinaram o manifesto nada menos que Marc Augé - então presidente da École de Hautes Études em Sciences Sociales - George Balandier, Maurice Godelier, Françoise HeritierAugé, Michel Leris e Jean-Pierre Vernant, entre outros.

Mas o projeto acabou mudando de rumo e, além do pavilhão de arts premiers, inaugurado no Pavillon des Sessions do Louvre, em 2001, a comissão Friedmann lançou a idéia de criar uma nova instituição para acolher os acervos do Musée de l'Homme e do Musée des Arts de l’Afrique et de l’Oceanie. Não se pode esquecer que, na França, todos os últimos presidentes procuraram deixar sua marca construindo grandes instituições culturais. Como lembrou o jornal Le Figaro de 1ํ de outubro de 1996: “Jacques Chirac à la tête de l’État, veut laisser sa marque [...] Ce sera la signature de son septennat, dans le domaine culturel. Comme Beaubourg pour Georges Pompidou, Orsay pour Valéry Giscard d'Estaing, ou le Grand Louvre pour François Mitterand” (Dupaigne, 2006, p. 36).

Essas obras custaram caro aos cofres públicos e era isso que os contribuintes temiam quando foi anunciada a construção do Musée Branly. Logo após a inauguração, por exemplo, um grupo de manifestantes autodenominado "tribo de contribuintes” fez uma performance de protesto no jardim do museu, vestindo roupas feitas com declaração de impostos e segurando moedas partidas ao 


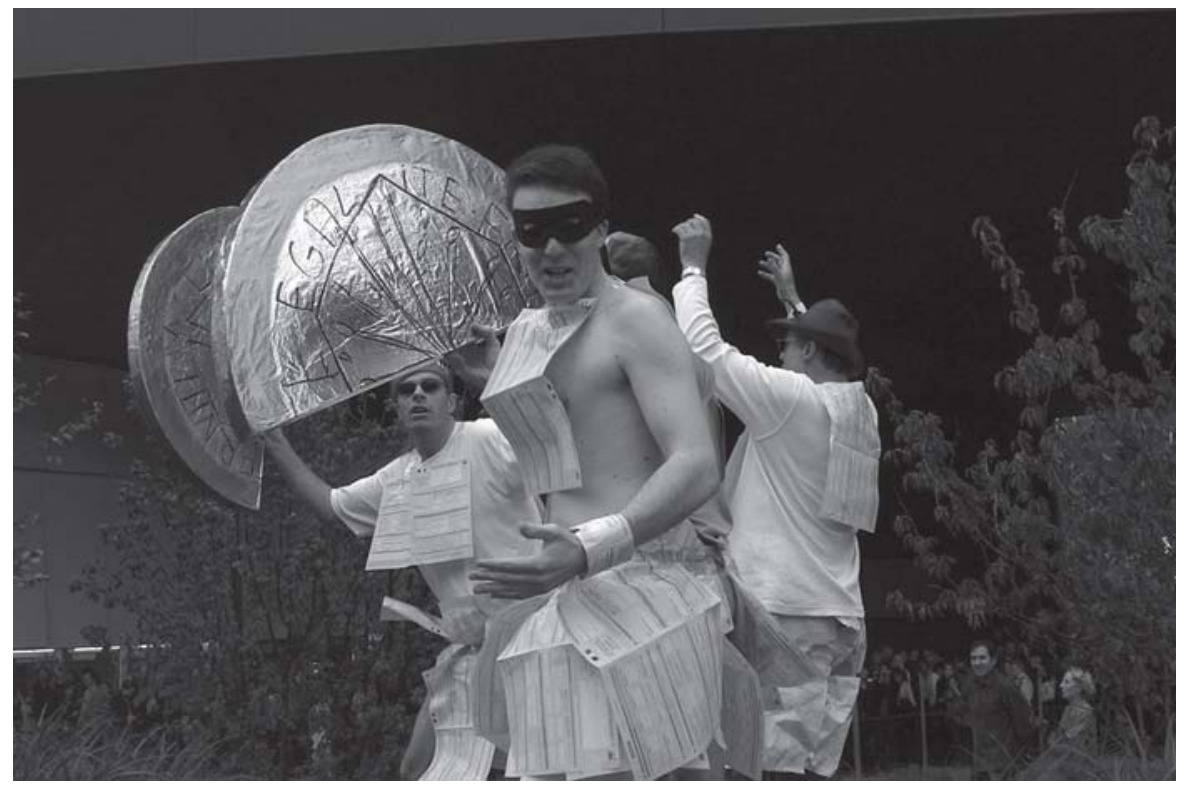

Figura 6. Manifestação da Brigade de l'argent des français (BAF), representando a "tribo dos contribuintes", em frente ao Musée Branly, em fevereiro de 2006. Foto: Joel Francois.

meio como se fossem objetos rituais. ${ }^{11}$ De fato, os 150 milhões de francos gastos em 2001, apenas com aquisições, para completar as lacunas do acervo do Musée Branly, eram exatamente a mesma quantia gasta por todos os outros museus franceses naquele ano ${ }^{12}$ (Dupaigne, 2006, p. 117).

Pairava no ar a suspeita de que essa súbita visibilidade das artes “primitivas” teria como finalidade principal a valorização desse segmento do mercado de arte, o que de fato ocorreu. Mas, acima de tudo, a querela se dava entre os adeptos da valorização formal das peças oriundas de sociedades não-ocidentais e os defensores de sua contextualização enquanto vias de acesso a outras culturas. Na verdade, o debate não é novo, mas foi reavivado e redesenhado pelo advento de Branly.

${ }^{11} \mathrm{O}$ vídeo da manifestação está disponível no endereço: http://br.youtube.com/watch?v=DLllG5ItJeM.

${ }^{12}$ De acordo com a agência Reuters, o custo total do projeto de instalação do Museu Branly foi de cerca de 235 milhões de euros (Blaschke, 2006).

Horizontes Antropológicos, Porto Alegre, ano 14, n. 29, p. 279-314, jan./jun. 2008 
Jacques Kerchache sustentava que a beleza plástica das obras-primas seria capaz de falar por si só. Alguns etnólogos discordavam, afirmando que adotar uma atitude exclusivamente estetizante frente a construtos culturais alheios é uma postura etnocêntrica e empobrecedora. Louis Dumont foi um dos que protestou: "Le projet du président de la République est directement réactionnaire. On nous propose de regarder les beaux objets d'ailleus à travers les préjugés des burgeois parvenus” (Dumont apud Dupaigne, 2006, p. 37).

\section{Artefato etnográfico, obra de arte, mercadoria}

Existem algumas tensões em relação ao modo de se lidar com a arte "primitiva” no Ocidente que se tornaram particularmente nítidas com a criação do Musée du Quai Branly. ${ }^{13}$ A primeira delas diz respeito à dicotomia entre tratar os artefatos como testemunhos etnográficos ou como criações estéticas. A segunda concerne às relações de poder envolvidas na aquisição dos objetos. A terceira tensão está ligada ao problema da autenticidade, numa era em que a globalização engendra a produção de souvenirs étnicos. A quarta concerne à atribuição de autoria e a datação, nas legendas das exposições.

Nos debates internacionais realizados por ocasião da inauguração do novo museu, ${ }^{14}$ todas essas tensões vieram à tona, de um modo ou de outro. $\mathrm{O}$ primeiro debate do evento de inauguração, “A metamorfose da qualificação”, girou em torno do binômio arte versus artefato. Susan Vogel, pesquisadora de arte africana da Columbia University, sustentou que um objeto impregnado de sentido por seus criadores e por sua cultura é um objeto artístico, ao passo que um

\footnotetext{
${ }^{13}$ Seria importante discutir também a pertinência e os limites do conceito de "arte" na abordagem dos fenômenos enfocados nesse artigo. Se nos guiarmos pela abordagem da sociologia da cultura (Bourdieu, 1989, 2003; Heinich, 1998), concluiremos que só existe arte nas sociedades ocidentais, pois só elas são dotadas de instâncias de consagração e profissionalização específicas. No entanto, dentro da antropologia há autores cuja concepção ampliada de arte permite aplicação a um número maior de manifestações culturais. É o caso de Alfred Gell (1998), por exemplo, para quem objetos artísticos são aqueles que suscitam reações no receptor e podem mesmo levá-lo a agir. Segundo Gell, a arte é relacional, reside naquilo que acontece com e por causa dos objetos - portanto, não é exclusiva das sociedades ocidentais.

${ }^{14}$ O seminário foi organizado por Bruno Latour, sob o nome Le Dialogue des Cultures; Encontres Inaugurales du Musée du Quai Branly. As atas do encontro, realizado dentro do museu, no dia 21 de junho de 2006, foram publicadas posteriormente (Latour, 2007).
}

Horizontes Antropológicos, Porto Alegre, ano 14, n. 29, p. 279-314, jan./jun. 2008 
objeto parecido com o primeiro, porém não dotado de significado especial é um simples artefato. Ao mesmo tempo, admitiu que um mesmo conjunto de objetos pode ser apreendido pelo público, ora pelo viés da antropologia - quando esses objetos são vistos enquanto produção coletiva/cultural -, ora pelo viés artístico - quando são considerados como criações individuais e únicas -, dependendo da maneira e do local em que ocorrer a exposição. ${ }^{15}$

Steven Hopper, diretor de pesquisas sobre artes da África, Oceania e América da Universidade de East Anglia, concordou com a relatividade da classificação dos objetos artísticos:

Il est important de comprendre que la classification ne porte pas sur des catégories fixes, mais veritablement sur des relations. [...] Pour moi, le rôle d'un musée [...] est de dissoudre ces anciennes distinctions entre art e artefact, entre objet d'art et objet ethnographique. Ces choses changent tout le temps. Il me semble qu'elles dépendent du contexte et qu'elles concernent véritablement les relations entre les objets réels et entre les personnes et les objets; ces personnes peuvent être des conservateurs, des chercheurs, des habitants de Fiji ou de Nouvelle-Zélande qui portent un intérêt à ces objets et qui les réinterpretent, les reclassifient constamment. (Hopper apud Latour, 2007, p. 30).

Se por um lado é política e cientificamente necessário explicitar o contexto original de fabricação dos objetos, por outro lado não se pode negar que diversas leituras serão suscitadas por eles, ao longo do tempo. Jean-Aimé Rakotoarisoa, diretor do Museu da Universidade de Antananarivo, em Madagascar, presente no debate inaugural, provocou: "enquanto profissionais dos museus, nós coletamos o objeto em um determinado momento e é apenas essa informação que aprisionamos em uma bela vitrine, com uma bela iluminação” (apud Latour, 2007, p. 44, tradução minha). É por isso que John Mack, historiador da arte da Universidade de East Anglia, propôs que se leve sempre em conta a "carreira dos objetos", o que abrangeria não apenas aspectos liga-

\footnotetext{
${ }^{15}$ Vale lembrar que o Center for African Art (hoje Museum of African Art) organizou, em 1988, uma exposição chamada ART/Artifact justamente para discutir o quanto o modo de exibição e o olhar do público é que definem se as peças são “objetos artísticos” ou simples “artefatos”. Na exposição, objetos muito semelhantes foram colocados em salas com ambientações diversas, que ajudavam a fazer deles ora obras de arte, ora peças de interesse etnográfico (Schneider, 2006, p. 34).
}

Horizontes Antropológicos, Porto Alegre, ano 14, n. 29, p. 279-314, jan./jun. 2008 
dos à sua proveniência e à sua aquisição, como igualmente as sucessivas mudanças na forma de interpretá-los e classificá-los.

Vislumbra-se aí uma primeira tensão, refletida na dicotomia de atitudes expositivas das instituições ocidentais em relação à arte "primitiva", que oscilam entre tratar seus construtos como testemunhos etnográficos ou como criações estéticas. Como explica Sally Price (2000, p. 134):

O ponto crucial do problema, como eu o vejo, é que a apreciação da arte primitiva tem sido quase sempre apresentada em termos de uma escolha falaciosa: uma opção é deixar o olho esteticamente discriminante ser o nosso guia, com base em algum conceito indefinido de beleza universal; a outra é enterrarmo-nos no saber tribal para descobrir a função utilitária ou ritual dos objetos em questão. Estes dois caminhos são geralmente vistos como contrários e incompatíveis, especialmente no contexto da exibição em museus onde, como já vimos, espera-se que os curadores escolham entre a "beleza" e a "antropologia” do seu material.

Além disso, a história da formação das coleções é obscura e há questões éticas e de tradução cultural implicadas. No ciclo de debates inaugurais do Musée Branly, Manuela Carneiro da Cunha lembrou a existência de um direito autoral moral inalienável, que garante ao autor de uma obra poder acompanhar a trajetória de sua criação, independentemente de havê-la vendido ou doado, e ser consultado quando houver modificações na obra (Latour, 2007, p. 109). Já John Friede, colecionador estado-unidense que faz parte do comitê de aquisições do Museu Branly, pronunciou-se a favor da autonomia dos museus e colecionadores em relação às sociedades tradicionais, para que possam preservar o que, de outro modo, se perderia no tempo e no espaço. Ele deu dois exemplos opostos: os seneca, da América do Norte, estão exigindo da fundação que ele dirige que seus objetos sejam destruídos e enterrados. John Friede contou que, "felizmente”, não é obrigado por lei a fazer isso. Por outro lado, um grupo da Nova Guiné ficou lisonjeado ao saber que havia artefatos seus na fundação dirigida por John Friede (Latour, 2007, p. 102).

Essa segunda tensão, relacionada às questões de poder e de propriedade intelectual envolvidas na apropriação da arte “primitiva”, pode também ser ilustrada por uma notícia recente que virou manchete em jornais do mundo todo. Em outubro de 2007, o tribunal de Rouen suspendeu a decisão do prefeito dessa cidade de devolver à Nova Zelândia uma cabeça maori tatuada, que estava há décadas no Muséum d’Histoire Naturelle de Rouen. As negociações 


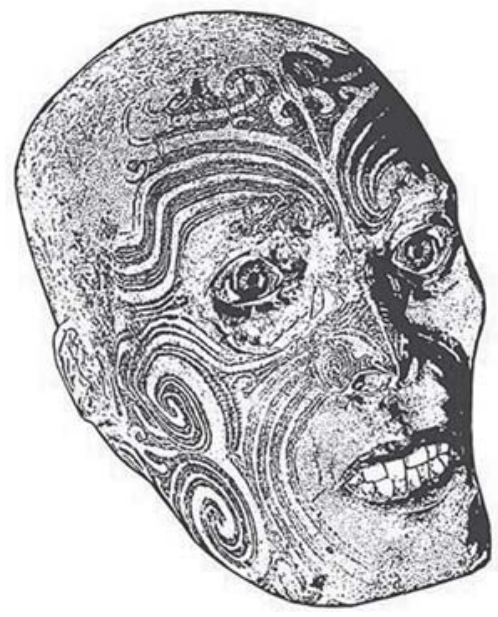

Figura 7. Desenho de cabecsa maori, tatuada e mumificada, que o Museu de Roven pretendia restituir à Nova Zelândia. Divulgacão. já haviam começado e os maori desejavam sepultar os restos mortais de um provável guerreiro morto em combate. Entretanto, a ministra francesa da cultura, Christine Albanel, paralisou o processo de devolução com base na lei Tasca, de 2002, que proíbe a venda de peças pertencentes a coleções públicas francesas, sem o parecer de uma comissão científica. O prefeito de Rouen, Pierre Albertini, havia considerado a cabeça maori como um vestígio humano, regido pela bioética, mas o tribunal considerou que se trata de uma obra de arte. Na verdade, o medo do governo francês é abrir um precedente que poderia levar à dilapidação de algumas coleções francesas (Roux, 2007). Mais uma vez, a resposta para o impasse não é simples, mas, como escreveu James Clifford, "the relations of power whereby one portion of humanity can select, value and collect the pure products of others need to be criticized and transformed” (Clifford, 1996, p. 213).

Em relação à terceira tensão, que opõe as idéias de autenticidade e falsificação, Anthony Appiah (1997) - que também esteve presente no colóquio de inauguração - alerta sobre o fato de que o sistema internacional de comércio artístico exige a fabricação artificial da alteridade. As produções artísticas dos países em desenvolvimento e das sociedades sem escrita servem, nesse contexto, para satisfazer o desejo euro-americano de encontrar um Outro exótico (Appiah, 1997). Compreendendo esse nicho de mercado, algumas sociedades africanas têm produzido e comercializado o que Appiah intitula escultura "neotradicional”, criada exclusivamente para o Ocidente, à maneira das peças genuinamente pré-coloniais (Appiah, 1997, p. 207).

Bastante próxima é a noção de "pseudotradicional”, empregada por Nelson Graburn (2006) para se referir aos artefatos indígenas feitos para corresponder aos estereótipos que o comprador projeta sobre a cultura do Outro. O artista nativo, nesses casos, cria conscientemente o efeito de autenticidade que se espera dele, optando por representar personagens e fatos familiares aos colecionadores, em estilos facilmente reconhecíveis ou bem aceitos. Graburn não 
condena a produção pseudotradicional. Ao contrário, sugere que, de alguma maneira, ela carrega a mensagem do tipo "nós existimos, somos diferentes, fazemos algo de que temos orgulho e que é unicamente nosso". A respeito da fabricação da autenticidade, Graburn (2006, p. 425) exemplifica:

The Makondo of Tanzânia, who only recently took up ebony carving because of poverty and displacement from Mozambique, have made the best use of this trend: they have developed two entirely new tourist art forms, the bindamu, purely realistic forms that are recognizable African, and the shetani, or spirit forms, which are semi-abstract. [...] Africans are "supposed" to be woodcarvers, and, even where they are not, they take up the métier and become good at it!

O problema das “falsificações” gerou polêmica nos debates do evento de inauguração do Musée Branly. Foi lembrado que os escultores da Groenlândia produzem peças no estilo de Henry Moore para agradar aos canadenses e esculpem peças figurativas em marfim para os habitantes do Alaska. Há mesmo casos em que se instala um eficiente modo de produção em série de souvenirs étnicos, que, para competir com artigos industriais, são simplificados, reduzidos ou aumentados de tamanho, despojados de detalhes e tornados mais "compreensíveis”. ${ }^{16} \mathrm{O}$ problema é que a idade é justamente um dos critérios de autenticidade mais acionados no mundo dos museus e dos colecionadores de arte “primitiva”. Normalmente, o autêntico é associado por esses especialistas ao pré-moderno. A raridade é outro critério que valoriza um artefato indígena no mercado especializado. Assim, existe uma bifurcação na produção de artefatos “pseudotradicionais”, como argumenta Ruth Phillips (2006, p. 444):

Multiple replication of the object - supply - is the essential precondition for a successful commodity trade, but this same condition empties the object of value for the rare art collector. In this sense, the collector's interest runs counter not only to that of the aboriginal producer but also to that of the tourist-collector.

\footnotetext{
${ }^{16}$ A produção de souvenirs remete ao problema do turismo pós-colonial, em que se constroem universos de cartão postal, "localidades turísticas de opereta que não têm mais nada a ver com a realidade e não passam de meras montagens de cenários” (Urry, 1996, p. 56). De acordo com Urry (1996), nessa modalidade de turismo, as oportunidades de se estabelecerem verdadeiras relações entre turistas e autóctones são raras. Costuma imperar a lógica do clichê, pois uma das partes está trabalhando para ganhar dinheiro, em posição subalterna.
} 
Essa terceira tensão, entre o autêntico e o falso, o pré-moderno e o globalizado, levou alguns participantes do debate inaugural do Branly a se posicionarem contra a abertura do museu a produções contemporâneas, propondo que o acervo se concentre em aquisições do século XIX e começo do XX, para garantir sua "autenticidade”, enquanto outros sugeriram, ao contrário, que artistas contemporâneos de sociedades não-ocidentais sejam convidados a intervir e expor no espaço. Essa segunda alternativa, vale mencionar, foi a adotada pelo National Museum of the American Indian, inaugurado em Washington, em 2004. Sob direção de Richard West, advogado e ativista de origem indígena, a instituição faz consultas sistemáticas às comunidades indígenas contemporâneas e envolve seus representantes, da programação educativa às escolhas museográficas ${ }^{17}$ (Degli; Mauzé, 2006, p. 148).

Em relação ao recorte temporal das coleções, há que se destacar o problema da datação imprecisa, que costuma caracterizar as exposições de arte "primitiva”; não é raro ver reunidas peças da Pré-História, do século XIX e outras contemporâneas, numa mesma sala, ou explicadas por um mesmo texto. Mas qual a relação entre os legados da Pré-História e a produção atual das populações indígenas? Robert Layton (2001) alerta para o fato de que não se pode nomear com um mesmo termo sociedades distantes mais de 5 mil anos umas das outras. As sociedades atuais não são "fósseis" do passado, de modo que a arte pré-histórica não deveria ser equiparada às artes indígenas de nossos dias.

À datação vaga ou ausente, soma-se a ausência de atribuição autoral nas peças expostas, seja por falta de informação das galerias e museus, seja por acreditarem que se trata de obras coletivas e anônimas. No entanto, a utilização do termo "artista" é recorrente entre os estudiosos de arte "primitiva". Maurice Godelier, em sua fala no debate inaugural do Musée Branly, ressaltou que, mesmo nas sociedades tradicionais, não é qualquer pessoa que é capaz de fabricar um objeto carregado do sentido e poder; somente alguns indivíduos

\footnotetext{
${ }^{17}$ O Bangerang Cultural Centre, criado em 1982, é um exemplo de museu inteiramente criado e gerido por aborígenes Bangerang. A instituição australiana se propõe a contextualizar os artefatos por meio de painéis cenográficos - dioramas - feitos pelo artista George Broening. Ver: http:// home.vicnet.net.au/ bangercc/choice.html.
} 
podem fazê-lo e a aprendizagem deste ofício pode levar muitos anos. Appiah (1997, p. 206) sintetiza o problema:

A arte africana, até recentemente, foi colecionada como propriedade de grupos “étnicos” e não de indivíduos e estúdios, de modo que não é incomum que nenhuma das peças da exposição Perspectivas ${ }^{18}$ tenha sido identificada na lista catalográfica pelo nome de um artista individual, embora muitas delas sejam do século XX (e ninguém há de ter-se surpreendido, em contraste, com o fato de a maioria delas ser gentilmente rotulada com o nome dos proprietários das coleções, basicamente particulares, em que hoje elas se encontram).

Eis alguns dos desafios a serem enfrentados pela nova instituição e por todos os pesquisadores que se interessam pela intersecção entre arte, antropologia e museologia.

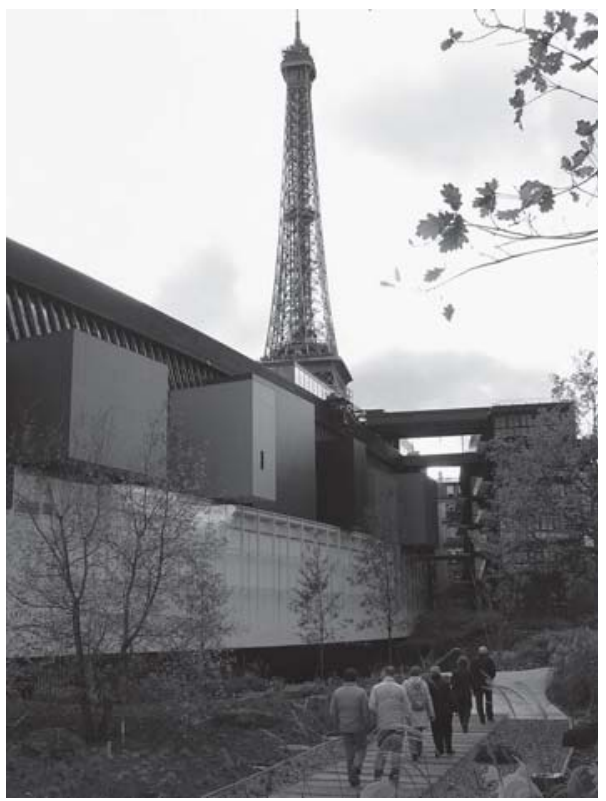

Figura 8. Fachada externa do Musée Branly. Divulgação.

\section{As muitas faces da arte "primitiva"}

Conforme constava no projeto inicial, o Musée du Quai Branly deveria chamar-se Musée des Arts Premiers. No entanto, a comunidade científica francesa se opôs fortemente a tal designação, em virtude de sua ambigüidade e de seu teor preconceituoso. Surpreendentemente, no Pavillon des Sessions, que é uma espécie de embaixada do Branly dentro do Louvre, usam-se, indistintamente, os adjetivos premier e primitif - o primeiro aparece no catálogo e o segundo nos painéis da exposição. Premiers, em francês, denota ao mesmo tempo anterioridade temporal e proximidade ao ${ }^{18}$ A exposição Perspectives: Angles on African Art, com curadoria de Susan Vogel, foi realizada pelo
Centro de Arte Africana de Nova Iorque, em 1987. 
estado original. Nesse sentido, não se está longe da proposta de André Malraux, ex-ministro da cultura que, na década de 1960, praticamente criou a política cultural francesa. Malraux propunha a valorização do que chamava de arts primordiaux (Dias, 2006).

É fácil compreender por que os cientistas, sobretudo antropólogos, manifestaram-se contra as expressões arts premiers e art primitif, no momento do batismo do novo museu. E só lembrar o contexto intelectual em que a crença na existência de sociedades "primitivas", no sentido de "menos evoluídas", tornou-se hegemônica: o evolucionismo, paradigma científico da segunda metade do século XIX. De acordo com autores evolucionistas como Morgan e Tylor, haveria uma pirâmide evolutiva entre as "raças" humanas, em cujo topo estariam os brancos caucasianos e em cuja base estariam negros e índios, povos “menos evoluídos” (Perry, 1998; Schwarcz, 1993).

Para a maioria do público burguês dessa época, a palavra [primitivo] significava povos e culturas atrasados e incivilizados. Numa época em que os franceses, como os britânicos e os alemães [...] criavam museus etnográficos e várias formas de estudo antropológico institucionalizado, os artefatos dos povos colonizados eram vistos amplamente como prova de sua natureza incivilizada, "bárbara”, de sua falta de "progresso" cultural. (Perry, 1998, p. 5).

Na verdade, desde o século XX, a noção de arte "primitiva” vem sendo usada como um guarda-chuva semântico, que engloba manifestações tão distintas como colagens feitas por pacientes psiquiátricos, pinturas pré-históricas e artefatos produzidos por cidadãos ocidentais sem instrução artística. É importante apresentar rapidamente cada um desses fenômenos: a arte bruta, a arte naïf ou popular, a arte pré-histórica e as artes indígenas. Embora sejam completamente diferentes, as quatro recebem ou receberam o rótulo de "primitivos".

A expressão arte "bruta” foi cunhada pelo artista plástico Jean Dubuffet para designar seu ideal: uma arte não lapidada por constrangimentos sociais e capaz de traduzir diretamente impulsos e desejos do artista. Em 1948, Dubuffet fundou a Companhia de Arte Bruta, junto com André Breton e, no ano seguinte, publicou o manifesto A Arte Bruta Preferida às Artes Culturais. O pressuposto de Dubuffet era que as produções artísticas capazes de escapar aos cânones e às instituições seriam mais genuínas e livres. Não apenas o artista francês passou a colecionar pinturas e esculturas confeccionadas por internos 
de manicômios - que depois doou ao museu de Lausanne -, como procurou pintar, ele próprio, de modo similar aos artistas "brutos". ${ }^{19}$

De acordo com Michel Thévoz (1990, p. 34-35, tradução minha), atual curador do Museu de Arte Bruta de Lausanne, um dos mais importantes do mundo, no gênero:

As obras brutas são suportes para a alucinação e o caos psíquico interior. O processo criativo dos artistas se desencadeia em impulsos imprevisíveis, de maneira análoga a um surto psicótico. Suas obras falam numa linguagem inventada, com uma lógica própria, que responde apenas a demandas interiores e inconscientes ao contrário da arte oficial.

Um nome de destaque, nesse campo, é o da médica alagoana Nise da Silveira, fundadora do Museu de Imagens do Inconsciente, no Rio de Janeiro. Ela criou uma metodologia para dar vazão ao inconsciente por meio das formas e cores e manteve, por muito tempo, correspondência com o psicólogo Carl Jung, que ficou impressionado com a riqueza plástica da produção dos brasileiros, nas duas vezes em que esteve no Rio (cf. Frayze-Pereira, 2003).

Os exemplos de artistas "brutos" brasileiros que agradam à crítica e aos colecionadores são numerosos. Bispo do Rosário ${ }^{20}$ é o caso mais emblemático, mas há outros, como Moacir, protagonista de um documentário de Walter de Carvalho ${ }^{21}$ e Antonio Roseno de Lima, descoberto por um professor do Instituto de Artes da Unicamp. Antonio Roseno de Lima, que vivia em uma favela de Campinas, pintava com guache sobre fotos que ele mesmo tirava, desenhava imagens que provocavam ilusão de ótica ou que lembravam a arte pop.

\footnotetext{
${ }^{19}$ A arte bruta muitas vezes nasce da arte-terapia. Hanz Prinzhorn foi quem usou pioneiramente a arte como forma de tratamento de psicoses e da esquizofrenia, numa clínica em Heildelberg, na década de 1920, dando origem à primeira coleção de “arte bruta” de que se tem notícia. Essa clínica foi tomada pelos nazistas em 1933 e a coleção foi usada para equiparar artistas modernos como Paul Klee, Van Gogh, Kandinsky e Chagall a “degenerados” mentais.

${ }^{20}$ Bispo do Rosário teve uma visão com um cortejo de anjos que lhe traziam uma mensagem de Deus, ordenando-lhe que registrasse sua passagem sobre a Terra. Após esse episódio, peregrinou por clínicas e hospícios, produzindo obsessivamente estandartes, murais, bordados e outras peças a partir de panos velhos e sucata. Após sua morte, foram catalogados cerca de 900 trabalhos, que escaparam do descaso porque foram requisitados pelos organizadores da Bienal de Veneza, em 1995 (Hidalgo, 1996).

${ }^{21}$ O documentário se chama Moacir, Arte Bruta (2006).
} 
Ele foi chamado pelos jornalistas de “pintor pop da favela”, porque seus quadros misturavam imagens, fotografias, propagandas e palavras como nos cartazes comerciais. [...] Queria ver sua pintura nos outdoors da cidade e perguntava-me como realizar isso. [...] Quando ele morreu em 1998, pobre e doente, uma grande parte dos seus trabalhos estava em coleções de arte no Brasil e no exterior e outra grande parte jogada no lixão pelo caminhão da prefeitura chamado pela família para limpar a casa. (Porto, 2001).
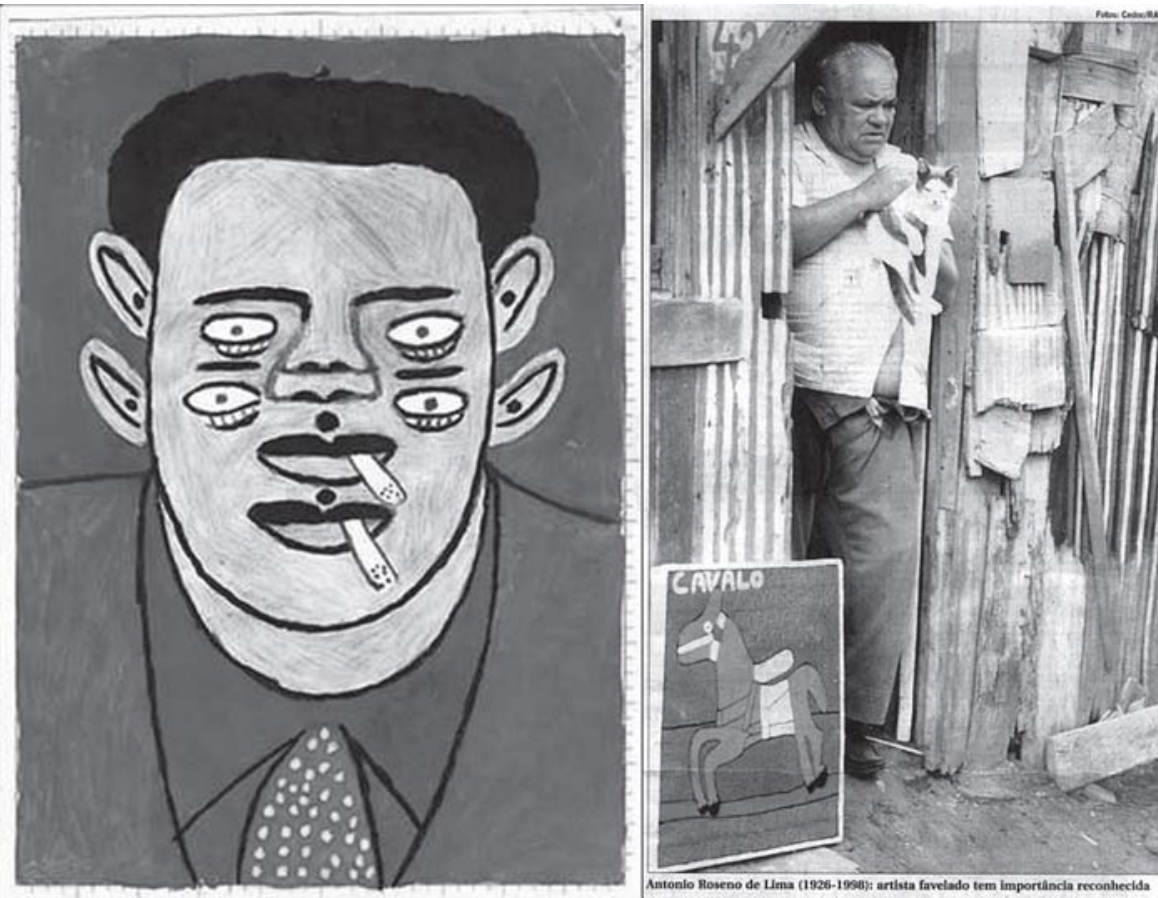

Figura 9. "Bêbado", de Antonio Roseno de Lima, sem data. Acervo do Centro de Memória da Unicamp; reportagem sobre o artista "bruto" Antonio Roseno de Lima no Correio Popular. Campinas, 26 de marco de 2006.

Já a arte naïf aparece principalmente no discurso de galeristas que vendem pinturas coloridas e hiper-realistas, marcadas pela espontaneidade e pela ausência de aspectos acadêmicos, como regras de composição e perspectiva. Naïf significa "ingênuo" em francês, e o termo sugere uma associação com um suposto estado de pureza. Henri “Douanier” Rousseau (1844-1910) foi, prova-

Horizontes Antropológicos, Porto Alegre, ano 14, n. 29, p. 279-314, jan./jun. 2008 
velmente, o primeiro pintor considerado naïf de que se tem notícia. Esse alfandegário francês foi descoberto no final do século XIX, no Salão dos Independentes, e acabou aclamado por artistas consagrados como Apollinaire, Delaunay e Picasso. No Brasil, foi somente na década de 1950 que se começou a dar atenção aos artistas populares, com as primeiras exposições de Heitor dos Prazeres e José Antônio da Silva. As décadas de 1960 e 1970 conheceram uma verdadeira explosão de pintores “ingênuos” brasileiros.

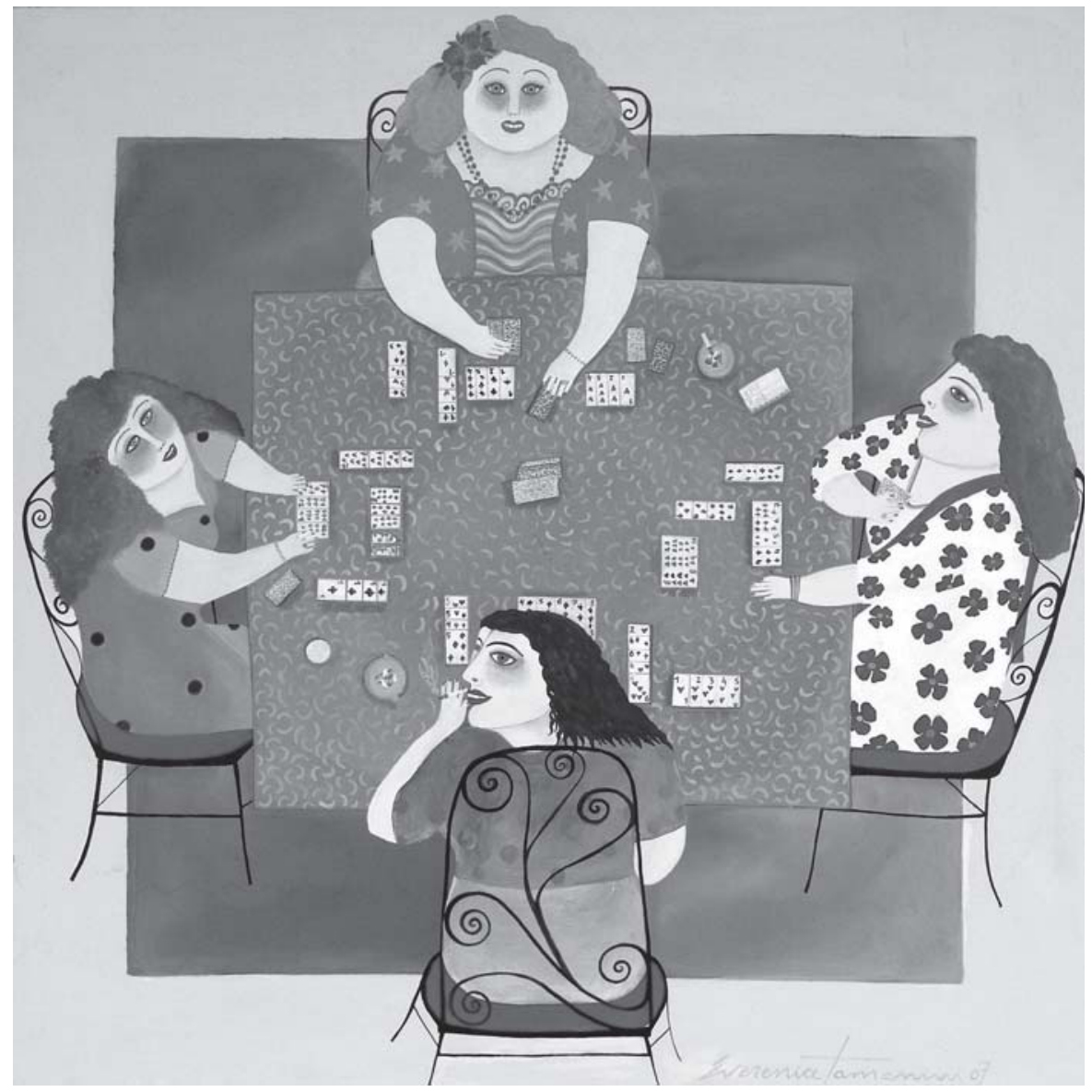

Figura 10. Jogo de Baralho, 2007, de Everenice Tamanini, representada pela Galeria Brasiliana. Reprodução autorizada pela artista. 
Existem no Brasil várias galerias especializadas em arte popular, como a Jacques Ardies e a Brasiliana, ${ }^{22}$ ambas em São Paulo. O motivo pelo qual esse tipo de expressão cultural costuma ser chamada de "primitiva” é o autodidatismo dos autores, cuja criação é definida pelos marchands como "instintiva e espontânea, realizada por pintores [...] que, alheios aos movimentos artísticos, sociais e culturais de sua época, criam unicamente movidos por suas emoções”. ${ }^{23}$

Com efeito, no início dos anos 1970, os artistas naïf - ou populares, como preferem alguns - eram conhecidos no Brasil como "primitivos", em virtude de não terem formação artística e de serem de origem social humilde. A utilização do termo "primitivo" foi diminuindo gradualmente, com o aumento do reconhecimento da arte popular no mercado. Mas não desapareceu.

Artefatos da pré-história constituem o terceiro conjunto que aparece sob o rótulo de arte "primitiva”. Segundo Michel Lorblanchet (1997), a representação figurativa data de 35 mil anos, quando teria ocorrido uma verdadeira "revolução mental” no Homo sapiens. São dessa época as estatuetas e as pinturas rupestres mais antigas, que surgem mais ou menos ao mesmo tempo em diversas regiões do planeta, provavelmente associadas a uma nova espiritualidade. Muitas pinturas foram achadas em salões profundos, onde até espeleólogos têm dificuldade de entrar, indicando uma possível ligação com práticas xamânicas individuais. Outras têm grandes dimensões, como se tivessem sido criadas para ser vistas, em salas que comportam cerimônias coletivas. A pintura rupestre brasileira, tão abundante quanto pouco conhecida, contém cenas de seres humanos realizando suas atividades numa proporção muito superior à das cavernas européias ${ }^{24}$ (Guidon; Martin; Pessis, 2004).

\footnotetext{
${ }^{22}$ Embora, em geral, os adjetivos naïf e popular sejam atribuídos aos mesmos artistas, existe uma disputa simbólica interessante entre Jacques Ardies, proprietário da galeria que leva seu nome, e Antonio Ruggiero, dono da Galeria Brasiliana. O primeiro se apresenta como o grande descobridor da arte naïf no Brasil - comprada por estrangeiros ávidos por um exotismo palatável. O segundo se proclama representante da "verdadeira" arte popular brasileira, acusando os pintores naïf de produzirem em série e para mercado.

${ }^{23}$ Depoimento de Jacques Ardies no site da sua galeria (http://www.ardies.com/quem.htm).

${ }^{24}$ Os sítios arqueológicos rupestres mais importantes do Brasil encontram-se em Naspolini (Santa Catarina), Lagoa Santa e Varzelândia (Minas Gerais), Toca da Esperança (Bahia) e Serra da Capivara (Raimundo Nonato - Piauí). Só em Raimundo Nonato, há 590 focos de pintura rupestre, constituindo a maior concentração de motivos por metro quadrado do mundo. Inicialmente, foram datadas de 12 mil anos, mas hoje algumas pesquisas apontam para uma data anterior (Guidon; Martin; Pessis, 2004).
} 
O último grupo de manifestações estéticas que é freqüentemente classificado como "primitivo" é o das artes indígenas contemporâneas. Embora muito diversas entre si, elas têm em comum a efemeridade - não são feitas para durar - e o respeito à tradição - já que a eficácia vale mais do que inovação. São muitas as linguagens das artes indígenas, englobando desde a vertente performática (canto e dança), até o artesanato utilitário (bancos e cerâmicas), passando pelas máscaras rituais, adornos plumários e pinturas sobre a pele.

Eis uma definição da especialista Lucia Hussak Van Velthen para as artes indígenas, que relaciona expressões estéticas e cosmologia:

Essas produções revelam dimensões do universo mítico e metafísico, assim como transmitem preocupações eminentemente comunitárias e identitárias, almejando, sob certo aspecto, ao título de "auto-retrato". [...] Os objetos transmitem conhecimentos acerca da imagem que seus produtores fazem de si mesmos e referendam as diferentes formas de veicular essa imagem. [...] Nas sociedades indígenas, a arte serve sobretudo para ordenar e definir o universo, uma vez que é parte integrante da função cognitiva global. (Van Velthen apud Aguilar, 2000, p. 60-68).

Exemplo eloqüente são as máscaras gigantes dos Waurá, do Xingu, criadas e usadas exclusivamente em rituais de cura. Elas "andam” sempre em dupla, sendo uma "macho" e a outra "fêmea”. Presentificam as entidades patogênicas reveladas pelos sonhos do xamã, daí seu visual onírico e assustador. Durante o ritual, as máscaras dançam ao som de três enormes flautas que

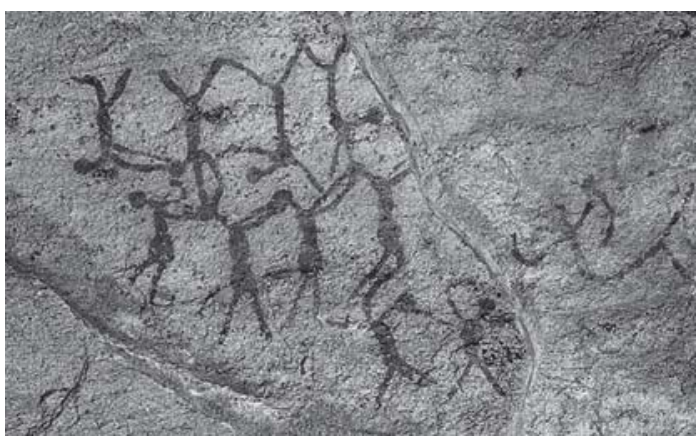

Figurall. Pintura rupestre em Raimundo Nonato (PI), datada de 50 mil anos. Divulgacão. só os homens podem ver e tocar. Apesar de utilizarem somente as cores amarela, vermelha e preta, os Waurá obtêm grande variedade por meio da combinação de 12 formatos diferentes e de inúmeros tipos de grafismos geométricos ou zoomorfos (Barcelos Neto, 2002). Há pouquíssimos exemplares dessas máscaras em museus, pois 
os Waurá não as vendem, nem dão para gente de fora. São feitas para ganharem a vida por um instante e depois desaparecem. ${ }^{25}$

Existem dois critérios de classificação que aproximam todas essas expressões artísticas e fazem com que elas caibam na categoria de arte "primitiva”, ao menos no senso comum. O primeiro critério é a associação entre esses processos de criação e os impulsos humanos instintivos e "genuínos”, supostamente predominantes em estágios arcaicos da evolução da espécie, em indivíduos com baixo nível de instrução formal ou em pessoas cujo inconsciente efervescente invade as fronteiras da consciência. O segundo critério reside na posição marginal de seus produtores, seja em relação à “normalidade” psíquica (arte bruta), seja em relação à cultura erudita (arte naïf ou popular), seja em relação a um menor grau evolutivo (arte pré-histórica) ou à supremacia econômica e tecnológica da sociedade Ocidental (artes indígenas).

No caso das artes não-ocidentais expostas no Musée Branly, o primeiro ponto é facilmente desmentido. Longe de serem criações impulsivas e instintivas, as artes indígenas exigem um enorme aprendizado: a respeito das matérias-primas empregadas; das técnicas; dos momentos adequados para a confecção; das interdições de idade, sexo, status, etc. ligadas a cada material ou linguagem; do repertório decorativo do grupo; de seu repertório mítico; do uso e da forma de armazenamento de cada item, etc. Quanto ao segundo ponto, trata-se do velho problema do etnocentrismo.

Quando se designam as artes indígenas contemporâneas como "primitivas”, o que está em jogo é a equiparação entre sociedades tradicionais atuais e grupos pré-históricos, como se índios fossem seres do passado. Além disso, do ponto de vista técnico, "primitivo" sugere algo menos sofisticado, tosco, malfeito. Contudo, as inúmeras provas de habilidades manuais indígenas devem advertir-nos "contra a crença de que as obras deles parecem grotescas porque não faziam melhor. Não é o padrão de capacidade artística desses artífices que difere dos nossos, mas as idéias deles” (Gombrich, 1988, p. 24).

Curiosamente, a arte "primitiva”, em suas várias facetas, costuma agradar ao grande público mais do que a arte ocidental contemporânea. Talvez

${ }^{25}$ Em 2005, os Waurá viajaram do Xingu para a França, para fazer um ritual dentro da programação de um festival de Montpelier. Foi assim que o Musée Branly conseguiu adquirir algumas máscaras para a sua coleção - tradicionalmente, os patrocinadores da festa têm direito sobre as máscaras (Barcelos Neto, comunicação pessoal, 2006).

Horizontes Antropológicos, Porto Alegre, ano 14, n. 29, p. 279-314, jan./jun. 2008 
porque, como aponta Heinich (1998), a arte contemporânea faça entrarem em crise os princípios canônicos que definem tradicionalmente as obras de arte, desde a noção de figuração até a própria idéia de invenção e de beleza, engendrando um vazio de significado no público. Isso poderia explicar, em parte, o interesse atual por obras "primitivas" - figurativas, por vezes utilitárias, portadoras de mensagens passíveis de serem decifradas e, supostamente, mais fáceis de compreender. Ledo engano...

\section{Considerações finais}

Ao examinarmos as artes não-ocidentais, estamos diante de objetos que operam, simultaneamente, como testemunhos etnográficos de outras culturas aos olhos ocidentais, como manifestações estéticas com forte poder de comunicação, no seio das comunidades em que são produzidas, e como mercadorias com valor de troca, no mercado global. Trata-se de dimensões distintas, sobrepostas e interrelacionadas. Pode-se até priorizar uma ou outra dimensão, mas é fundamental não perder de vista as demais. Assim, a abordagem predominantemente estética que deu a tônica do projeto Branly, desde o início, continua a merecer debate.

Quando se criou o Musée Branly, partiu-se da idéia de que os objetos produzidos por sociedades sem escrita contêm as premissas da expressão artística mais genuína da Humanidade. Portanto, deveríamos apreendê-los por meio da emoção estética. Os idealizadores do Branly pareciam acreditar que as peças da coleção seriam capazes de veicular uma verdade profunda, impenetrável ao discurso racional e acessível somente pela via sensível (Dias, 2006).

Ora, Lévi-Strauss já mostrou que a introdução da escrita e o advento do individualismo obscureceram, entre nós, o papel de linguagem que a arte ocupa nas sociedades tradicionais. O antropólogo francês diferencia a arte ocidental da "primitiva” com base em dois fatores. O primeiro é a tendência à representação na arte ocidental, ao passo que a arte "primitiva”, ao invés de reproduzir modelos, comunica, funcionando como um sistema de signos. O segundo é que a recepção artística é mais individualizada nas sociedades modernas. Nas sociedades tradicionais, ao contrário, é a coletividade que espera do artista que ele lhe forneça certos objetos confeccionados de acordo com os cânones e códigos culturais (Lévi-Strauss, 1989).

Justamente por isso, não é possível negligenciar todos os aspectos intangíveis que envolvem os artefatos materiais das sociedades não-ocidentais, desta- 
cado apenas o objeto visível e colecionável. Como afirmou Daniel Maxim, referindo-se ao novo museu parisiense, “um objet n'a aucun sens sans l'immatériel qu'il peut de manière lumineuse renvoyer vers celui qui le regarde. C'est sa seule vocation" (apud Latour, 2007, p. 405).

Por outro lado, o partido estetizante do Musée Branly é, na realidade, parte de um movimento mais amplo, iniciado na década de 1980. A convicção de que é possível reconstituir uma sociedade a partir de sua cultura material caiu em descrédito e os museus etnográficos foram acusados de reificar e caricaturizar culturas alheias. ${ }^{26}$ Frente a essa crise, museus e exposições etnográficas começaram a buscar novas alternativas, dentre as quais a transformação em museus e exposições de arte (L’Estoile, 2007).

A dimensão estética é, hoje, uma das vias de acesso à diversidade cultural. E a diversidade cultural, por sua vez, foi eleita como valor universal pela Declaração Universal adotada pela Unesco no dia seguinte aos atentados de 11 de setembro. É nesse cenário que o Musée Branly se revela um objeto fértil para repensar várias questões clássicas da antropologia, tais como as (im)possibilidades de tradução cultural, o exercício de poder implicado na representação da alteridade, o problema da propriedade intelectual nas sociedades sem escrita, a relatividade dos padrões estéticos e a inserção das culturas tradicionais no mercado global.

\section{Referências}

AGUILAR, Nelson (Org.). Mostra do redescobrimento: artes indígenas. São Paulo: Fundação Bienal de São Paulo: Associação Brasil 500 anos de Artes Visuais, 2000.

APPIAH, Kwame Anthony. Na casa do meu pai: a África na filosofia da cultura. Rio de Janeiro: Contraponto, 1997.

\footnotetext{
${ }^{26}$ Em uma carta enviada em 1996 a Jacques Friedmann - presidente da comissão de artes "primeiras” - Lévi-Strauss afirmava que os museus de etnografia, hoje, não podem mais oferecer uma imagem autêntica de sociedades diferentes da nossa. Mas o motivo alegado por ele é surpreendente: “À quelques exceptions près, qui ne dureront pas, ces societés sont progressivement intégrées à la politique et à l'économie mondiales (apud Degli; Mauzé, 2006, p. 1).
} 
BARCELOS NETO, Aristóteles. A arte dos sonhos: uma iconografia ameríndia. Lisboa: Museu Nacional de Etnologia: Assírio \& Alvim, 2002.

BLASCHKE, Florian. Paris ganha museu do belo exotismo. Deutsche Welle, 23 jun. 2006. Seção Cultura. Disponível em: <http://www.dw-world.de/dw/article/ 0,2144,2065867,00.html>. Acesso em: 4 nov. 2007.

BOURDIEU, Pierre. O poder simbólico. São Paulo: Difel, 1989.

BOURDIEU, Pierre. O amor pela arte. São Paulo: Edusp: Zouk, 2003.

CLIFFORD, James. The Predicament of Culture. Massachussetts: Harvard University Press, 1996.

DEGLI, Marine; MAUZÉ, Marie. Arts premiers. Paris: Gallimard: Réunion des musées nationaux, 2006.

DIAS, Nélia. Qu'est-ce que les arts premiers? Sciences Humaines: dossier $\mathrm{n}$. 3, Paris: Musée du Quai Branly, p. 8-11, juin/août 2006.

DUPAIGNE, Bernard. Le scandale des arts premiers: la véritable histoire du Musée du Quai Branly. Paris: Mille et une nuits, 2006.

FRAYZE-PEREIRA, João. Nise da Silveira: imagens do inconsciente entre psicologia, arte e política. Estudos Avançados, v. 17, n. 49, p. 197-208, set./ dez. 2003.

GELL, Alfred. Art and agency: an anthropological theory. Oxford: Clarendon Press, 1998.

GOMBRICH, E. H. A história da arte. Rio de Janeiro: Guanabara, 1988.

GRABURN, Nelson. Arts of the Forth World. In: MORPHY, Howard; PERKINS, Morgan. The anthropology of art: a reader. Oxford: Blackwell Publishing, 2006. p. 412-430.

GUIDON, Niéde; MARTIN, Gabriela; PESSIS, Anne-Marie. Antes: histórias da pré-história. Rio de Janeiro: Centro Cultural Banco do Brasil, 2004.

HEINICH, Nathalie. Le triple jeu de l'art contemporain. Paris: Minuit, 1998. HIDALGO, Luciana. Arthur Bispo do Rosário: o Senhor do Labirinto. São Paulo: Rocco, 1996. 
KROEBER, Theodora. Ishi in two worlds: a biography of the last wild Indian in North America. Berkeley: Univeristy of California Press, 1961.

LATOUR, Bruno (Org.). Les dialogues des cultures: actes des rencontres inaugurales do Musée du Quai de Branly (21 juin 2006). Paris: Musée du Quai Branly, 2007.

LAYTON, Robert. A antropologia da arte. Lisboa: Edições 70, 2001.

LÉVI-STRAUSS, Claude. Des symboles et leur doubles. Paris: Plon, 1989.

L'ESTOILE, Benoît. Le gout des autres: de l'exposition coloniale aux arts premiers. Paris: Flammarion, 2007.

LORBLANCHET, Michel. La naissance de l'art: genèse de l'art préhistorique. Paris: Errance, 1997.

MOACIR, arte bruta. Roteiro e direção: Walter Carvalho. Produção: Marcello Maia, Eliane Soárez e Maria Clara Ferreira. Fotografia: Lula Carvalho. Edição: Pablo Ribeiro. Estúdio: República Pureza; Kinofilm; Leblon 3. Distribuição: Riofilme. Rio de Janeiro, 2006. 1 DVD.

MUSÉE DU QUAI BRAINLY. Masterpieces from the Musée du Quai Brainly collections. Paris, 2006.

PERRY, Gill. O primitivismo e o "moderno”. In: HARRISON, Charles et al. Primitivismo, cubismo e abstração: começo do século XX. São Paulo: Cosac \& Naify, 1998. p. 3-85.

PHILLIPS, Ruth. The collecting and display of souvenir arts. In: MORPHY, Howard; PERKINS, Morgan. The anthropology of art: a reader. Oxford: Blackwell Publishing, 2006. p. 431-453.

PORTO, Geraldo. Antonio Roseno de Lima, fotógrafo e pintor. Studium, n. 7, primavera 2001. Disponível em: <http://www.studium.iar.unicamp.br/sete/ 6.html>. Acesso em: 3 maio 2006.

POSSAS, Helga Cristina Gonçalves. Classificar e ordenar: os gabinetes de curiosidades e a história natural. In: FIGUEIREDO, Betânia Gonçalves; VIDAL, Diana Gonçalves (Org.). Museus: dos gabinetes de curiosidades à museologia moderna. Belo Horizonte: Argumentum, 2005. p. 151-162. 
PRICE, Sally. Arte primitiva em centros civilizados. Rio de Janeiro: Editora UFRJ, 2000.

PRICE, Sally. Paris primitive. Chicago: The University of Chicago Press, 2007.

ROUX, Emmanuel de. La route des sculptures Nok va-t-elle être coupée? 2000. Disponível em: <http://www.memoiredafrique.com/fr/nok/polemique.php>. Acesso em: 10 jan. 2008.

ROUX, Emmanuel de. L'affaire de la tête maori rouvre le débat sur la vente des oeuvres. 2007. Disponível em: <http://www.lemonde.fr/cgi-bin/ ACHATS/acheter.cgi?offre=ARCHIVES\&type_item=ART_ARCH _30J\&objet_id=1010166\&clef=ARC-TRK-D_01>. Acesso em: 10 jan 2008.

RUBIN, William (Org.). Primitivism in 20th century art: affinity of the tribal and the modern. New York: The Museum of Modern Art, 1984.

SCHNEIDER, Arnd. Appropriations. In: SCHNEIDER, Arnd; WRIGHT, Cristopher. Contemporary art and anthropolgy. Oxford: Berg, 2006. p. 2951.

SCHWARCZ, Lilia. O espetáculo das raças: cientistas, instituições e questão racial no Brasil: 1870-1930. São Paulo: Companhia das Letras, 1993.

SCHWARCZ, Lilia K. A era dos museus de etnografia no Brasil: o Museu Paulista, o Museu Nacional e o Museu Paraense em finais do XIX. In: FIGUEIREDO, Betânia Gonçalves; VIDAL, Diana Gonçalves (Org.). Museus: dos gabinetes de curiosidades à museologia moderna. Belo Horizonte: Argumentum, 2005. p. 113-136.

THÉVOZ, Michel. Art brut, psychose et médiumnité. Paris: La Différence, 1990.

URRY, John. O olhar do turista. São Paulo: Nobel, 1996.

VIANNA, Hermano. O exotismo nosso de cada dia. Folha de S. Paulo, São Paulo, 16 maio 2004. Caderno Mais!, p. 8-9. 